\title{
Lakes as buffers of stream dissolved organic matter (DOM) variability: Temporal patterns of DOM characteristics in mountain stream-lake systems
}

\author{
Keli J. Goodman, ${ }^{1,2}$ Michelle A. Baker, ${ }^{1}$ and Wayne A. Wurtsbaugh ${ }^{3}$ \\ Received 18 March 2011; revised 26 August 2011; accepted 1 September 2011; published 29 November 2011.
}

[1] Lakes within fluvial networks may affect dissolved organic matter (DOM) dynamics in streams by dampening spring DOM snowmelt flushing responses and/or by increasing summer DOM production. We assessed the temporal variability of dissolved organic carbon (DOC) concentration and DOM characteristics (specific ultraviolet absorbance $\left(\mathrm{SUVA}_{254}\right)$; DOC:dissolved organic nitrogen (DOC:DON)), as well as DOC export in seven paired lake inflows and outflows in the Sawtooth Mountain lake district, Idaho. We hypothesized that lakes would decrease stream DOM temporal variability and increase DOM export as a result of autotrophic production. We correlated DOM variability with landscape factors to evaluate potential drivers of DOM temporal patterns (measured as coefficient of variation). Coefficients of variation were $40-90 \%$ higher in lake inflows than outflows for DOC concentrations, characteristics, and DOC:DON. Increases in DOC concentrations on the ascending limb of the snowmelt hydrograph were greater in lake inflows than outflows, and on average mean DOC flux occurred 5.4 days earlier in the inflows than for the outflows. During base flow, mean outflow DOC concentrations were 1.7 times greater than inflows, and six outflows had higher annual export than inflows. Combined, these results illustrate that lakes alter the magnitude, timing and temporal variation of DOM concentration and characteristics exported from subalpine watersheds. This buffering effect results from a seasonal shift in the balance between hydrological versus biological controls on DOC dynamics, where lakes act as a sink during the spring when hydrologic controls dominate watershed DOM transport and act as a DOM source during summer.

Citation: Goodman, K. J., M. A. Baker, and W. A. Wurtsbaugh (2011), Lakes as buffers of stream dissolved organic matter (DOM) variability: Temporal patterns of DOM characteristics in mountain stream-lake systems, J. Geophys. Res., 116, G00N02, doi:10.1029/2011JG001709.

\section{Introduction}

[2] Chemical and physical properties of dissolved organic matter (DOM) alter mobility and transport of contaminants and heavy metals [Breault et al., 1996; McKnight et al., 1992], pH buffering capacity [McKnight et al., 1985], and light attenuation [Laurion et al., 1997; Scully and Lean, 1994; Williamson and Rose, 2009] in freshwaters. Since DOM is typically the largest bioavailable carbon source across the Earth's aquatic ecosystems [Benner, 2003] it can impact energy flow through food webs [Cole et al., 2006; Schiff et al., 1990]. The extent to which DOM can affect ecosystem functioning depends on DOM concentration,

\footnotetext{
${ }^{1}$ Department of Biology and Ecology Center, Utah State University, Logan, Utah, USA.

${ }^{2}$ Now at National Ecological Observatory Network, Boulder, Colorado, USA.

${ }^{3}$ Watershed Sciences Department and Ecology Center, Utah State University, Logan, Utah, USA.

Copyright 2011 by the American Geophysical Union. 0148-0227/11/2011JG001709
}

origin, age, structure, and chemical composition [Benner, 2003].

[3] DOM, operationally defined here as organic matter that passes through a $0.7 \mu \mathrm{m}$ filter [Kaplan, 1994], includes dissolved organic carbon (DOC), nitrogen (DON) and phosphorus. DOC is both the primary component of DOM and the constituent most directly measured. Hereafter, the term DOC will be used when discussing concentrations, while the term DOM will be used when discussing the entire molecule including chemical attributes. DOM chemical attributes, such as composition (i.e., DOC:DON ratios, lignin, etc.) and optical properties, have been used successfully to provide information on hydrologic flow paths [Hood et al., 2006], source material [Hood et al., 2005; McKnight et al., 1997], and quality (i.e., bioavailability) [Joffre et al., 2001]. Together, DOM characteristics can provide considerable information regarding chemical and physical changes to DOM, which over time, affect ecosystem functioning.

[4] Export of DOC from watersheds is a significant part of the global carbon cycle [Battin et al., 2009], and in most aquatic systems, this flux is driven by hydrological processes 


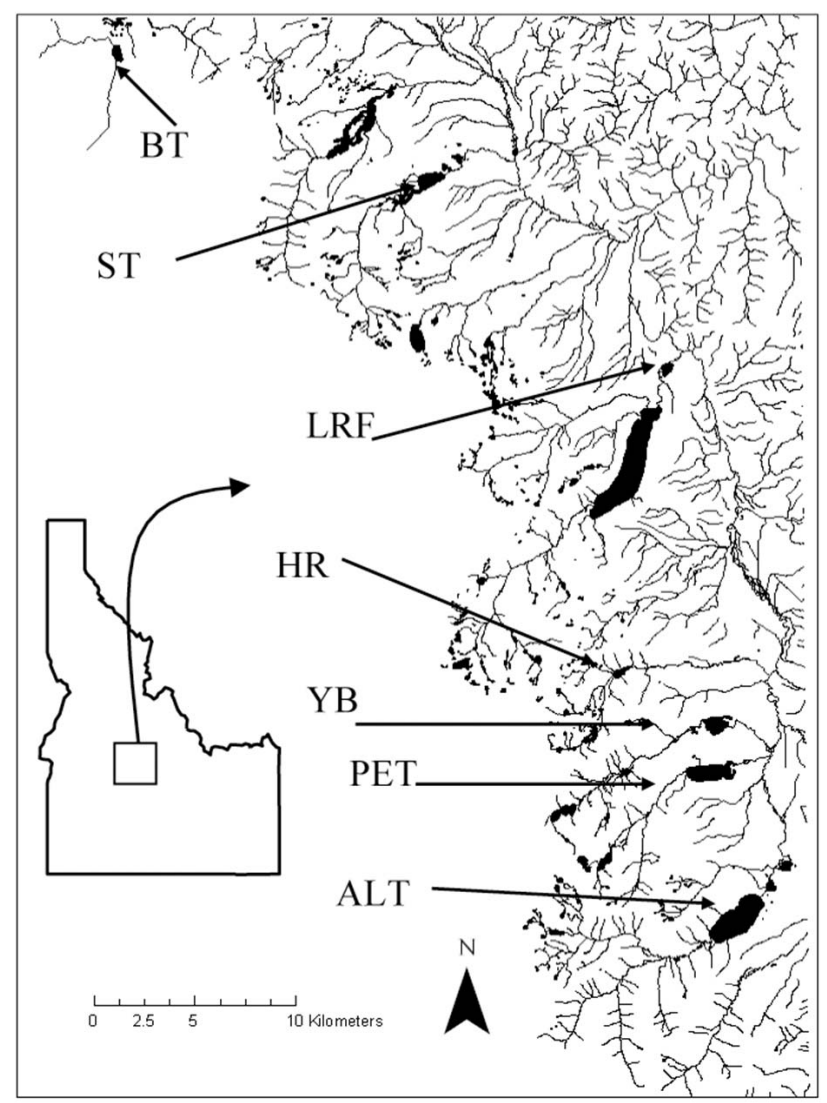

Figure 1. Map of study area in the Sawtooth Mountain lake district. Seven study lakes (ALT, Alturas; BT, Bull Trout; HR, Hell Roaring; LRF, Little Redfish; PET, Pettit; ST, Stanley; YB, Yellow Belly) are indicated by arrows. Inflow and outflow sampling stations were located within 550 stream meters of the study lakes and usually within $200 \mathrm{~m}$.

[Schlesinger and Melack, 1981]. In arctic [Finlay et al., 2006], alpine [Boyer et al., 1997], mountain [Baker et al., 2000], and boreal [Kortelainen et al., 1997] ecosystems, the majority of annual DOC flux is transported to streams during snowmelt runoff, when DOC concentrations peak prior to, or during, peak stream discharge and decline rapidly [Boyer et al., 1997; Lewis and Grant, 1979; Sebestyen et al., 2008]. This temporal pattern of DOC concentration in snowmeltdominated systems is attributed to flushing of pore water from the upper soil horizons as the water table rises [Hornberger et al., 1994] and represents the major source of DOM to these streams, typically exhausting the terrestrial DOM pool [Boyer et al., 1997].

[5] Contrary to DOM dynamics in streams, which are controlled largely by hydrologic processes and DOM sources [Boyer et al., 1997; Hornberger et al., 1994; Mulholland and Hill, 1997], DOM dynamics in lakes appear to be largely controlled by watershed characteristics related to landscape position and spatial extent of land cover [Kortelainen et al., 1997; Martin and Soranno, 2006; Mattsson et al., 2005; Riera et al., 2000; Soranno et al., 1999]. Lakes may also decrease stream DOM concentration and fluxes, as observed in boreal systems [Kortelainen, 1993; Mattsson et al., 2005;
Rantakari et al., 2004], although less is known about stream-lake interactions in oligotrophic alpine and subalpine systems.

[6] Lakes are present and common across many landscapes [Downing et al., 2006], yet lakes and streams have traditionally been studied as separate entities (but see Essington and Carpenter [2000] and Kling et al. [2000]). Lakes within fluvial networks are known to retain nitrogen [Lepistö et al., 2006], incorporate inorganic nutrients into organic matter [Kling et al., 2000], and may be a source of DOM during base flow [Brown et al., 2008]. Since lake DOC concentrations are less affected by hydrologic transport than are stream DOC concentrations, streams with upstream lakes may also be less affected by changes in discharge since water is first routed through a lake, where both water and nutrients may be stored [Kaste et al., 2003]. Thus, lakes may act to decrease the temporal variability of, or buffer, stream solute variability, and the extent of this effect may be related to water residence time [Ito et al., 2007; Kaste et al., 2003; Lepistö et al., 2006; Wurtsbaugh et al., 2005]. Additionally, in-lake processing can influence outflow stream nutrient dynamics [Ito et al., 2007] and DOM characteristics [Hood et al., 2003]. Thus, lakes may influence stream DOM dynamics by influencing both hydrological and biological factors that control DOM characteristics.

[7] The objectives of this research were to evaluate the effects of lakes on temporal patterns of DOM characteristics and annual export of DOC within mountain stream networks. Specifically, we ask: How do lakes alter the magnitude and timing of DOM export? What landscape and lake characteristics influence lake buffering of stream DOM dynamics? And what is the relative contribution of hydrological versus biogeochemical processes to that buffering?

[8] We addressed these questions by comparing DOM quantity, quality and flux in paired lake inflow and outflow streams in seven mountain watersheds. We quantified the timing of DOC center of mass export for the 2008 water year, evaluated relationships between DOC concentration and discharge, and analyzed the intra-annual variability and temporal patterns of DOM characteristics (UV light absorbing capacity and DOC:DON ratios). We then correlated the variability of DOM characteristics to watershed characteristics to elucidate the drivers of lake inflow and outflow temporal variability. Finally, we evaluated the extent to which lakes alter base flow DOC quantity and annual DOC export.

\section{Study Area}

[9] This study was conducted in paired lake inflows and outflows in seven catchments of the Sawtooth Mountain lake district $\left(44.11^{\circ} \mathrm{N}, 114.93^{\circ} \mathrm{W}\right)$ in central Idaho: Alturas (ALT), Bull Trout (BT), Hell Roaring (HR), Little Redfish (LRF), Pettit (PET), Stanley (ST), and Yellow Belly (YB) (Figure 1 and Table 1). HR Lake has two main inflows, hereafter referred to as HR1 and HR2. The lakes are fed by second or third order streams [Arp et al., 2007]. Inflow and outflow sampling locations were located within $20-550 \mathrm{~m}$ of the lakes.

[10] All of the lakes are formed behind terminal moraines deposited ca. 13 kya at the base of their respective watersheds at 1978-2258 m elevation [Borgert et al., 1999]; some watersheds also have upstream lakes behind younger 
Table 1. Lake and Watershed Characteristics of Seven Lake Inflows and Outflows in the Sawtooth Mountain Lake District, Central Idaho

\begin{tabular}{|c|c|c|c|c|c|c|c|c|c|c|c|c|c|c|}
\hline $\mathrm{WS}^{\mathrm{a}}$ & ID & $\begin{array}{l}\text { Inflow } \\
\text { WS } \\
\text { Area } \\
\left(\mathrm{km}^{2}\right)\end{array}$ & $\begin{array}{l}\text { Outflow } \\
\text { WS } \\
\text { Area } \\
\left(\mathrm{km}^{2}\right)\end{array}$ & $\begin{array}{l}\text { Lake } \\
\text { Area } \\
\left(\mathrm{km}^{2}\right)\end{array}$ & $\begin{array}{c}\text { Lake/WS } \\
\text { Area }\end{array}$ & $\begin{array}{c}\text { Lake } \\
\text { Volume } \\
\left({ }^{*} 10^{6} \mathrm{~m}^{3}\right)\end{array}$ & $\begin{array}{l}\mathrm{BF} \mathrm{Rt}^{\mathrm{b}} \\
\text { (years) }\end{array}$ & $\begin{array}{c}\text { Elev. }^{\mathrm{c}} \\
\text { (m) }\end{array}$ & $\begin{array}{l}\text { Distance to } \\
\text { Closest } \\
\text { Upstream } \\
\text { Lake }(\mathrm{km})\end{array}$ & $\begin{array}{l}\text { Volume of } \\
\text { Closest } \\
\text { Upstream } \\
\text { Lake } \\
\left({ }^{*} 10^{6} \mathrm{~m}^{3}\right)\end{array}$ & $\begin{array}{c}\text { Percent } \\
\text { Lake } \\
\text { Area }\end{array}$ & $\begin{array}{c}\text { Percent } \\
\text { Forest } \\
\text { Cover }\end{array}$ & $\begin{array}{l}\text { Percent } \\
\text { Veg. } \\
\text { Cover }\end{array}$ & $\begin{array}{c}\text { Percent } \\
\text { Barren } \\
\text { Area }\end{array}$ \\
\hline Alturas & ALT & 64.7 & 76.1 & 3.34 & 0.052 & $108.2^{* \mathrm{~d}}$ & 6.35 & 2139 & $\mathrm{NA}^{\mathrm{e}}$ & NA & 0.68 & 48.1 & 97.7 & 1.8 \\
\hline Bull Trout & BT & 10.3 & 11.6 & 0.25 & 0.027 & 1.28 & 0.30 & 2118 & NA & NA & NA & 75.2 & 99.9 & 0.0 \\
\hline Hell Roaring & $\mathrm{HR} 1^{\mathrm{f}}$ & 13.5 & 20.7 & 0.24 & 0.066 & 1.9 & 0.29 & 2258 & 2.96 & 2.54 & 1.81 & 21.9 & 81.1 & 15.8 \\
\hline Hell Roaring & $\mathrm{HR} 2^{\mathrm{f}}$ & 3.6 & & & & & & & 0.95 & 0.13 & 3.64 & 12.8 & 71.5 & 27.4 \\
\hline Little Redfish & LRF & 111.4 & 113.1 & 0.26 & 0.002 & 0.9 & 0.02 & 1978 & 2.64 & 273.24 & 6.43 & 46.1 & 86.0 & 7.3 \\
\hline Pettit & PET & 21.3 & 27.6 & 1.62 & 0.076 & $45.0^{*}$ & 6.96 & 2131 & 5.77 & 2.54 & 2.44 & 30.3 & 91.0 & 6.9 \\
\hline Stanley & ST & 31.9 & 40.4 & 0.86 & 0.027 & $10.4^{*}$ & 0.72 & 1985 & NA & NA & 0.46 & 62.7 & 97.9 & 1.7 \\
\hline Yellow Belly & YB & 26.3 & 30.0 & 0.79 & 0.030 & $10.3^{*}$ & 0.94 & 2157 & 0.73 & 0.25 & 3.16 & 34.2 & 88.2 & 9.1 \\
\hline
\end{tabular}

${ }^{\mathrm{a}} \mathrm{WS}$ is watershed.

${ }^{\mathrm{b}} \mathrm{BF} \mathrm{Rt}$ is lake residence time, calculated as lake volume/average base flow discharge. Rt calculations assume a completely mixed lake.

${ }^{\mathrm{c} E \text { Elevation. }}$

${ }^{\mathrm{d}}$ Asterisk indicates lake volumes from Budy et al. [1995].

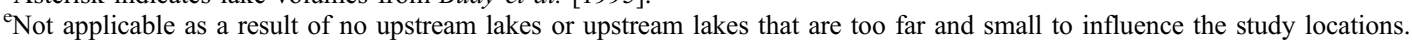

${ }^{\mathrm{f}} \mathrm{HR} 1$ and HR2 represent two different inflows to Hell Roaring Lake.

moraines and/or tarns formed in high-elevation cirque basins (Figure 1). Six (ALT, HR, LRF, PET, ST, YB) of the seven study watersheds lie within the Sawtooth National Recreation or Wilderness Area and drain into the Salmon River. BT watershed lies $20 \mathrm{~km}$ northwest of ST watershed within the Boise National Forest and drains into the South Fork Payette River.

[11] The Sawtooth Mountains are predominately granitic, and alkalinity and nutrient levels are consequently low [Budy et al., 1995]. This area is typically snow covered for 7-8 months, and peak spring snowmelt, occurring in late May or June, represents the dominant hydrologic flux in these systems. Watershed vegetation cover ranges from $70 \%$ to $100 \%$ (Table 1 ). Upland vegetation is dominated by lodgepole pine (Pinus contorta), while sedges (Carex sp.), willows (Salix sp.) and grasses dominate riparian areas [Arp et al., 2006]. All watersheds are relatively pristine with limited recreational land use and low wet atmospheric nitrogen (N) deposition $\left(\sim 1.0 \mathrm{~kg} \mathrm{ha}^{-1} \mathrm{yr}^{-2}\right)$ [National Atmospheric Deposition Program, 2001]. Lakes and streams are typically oligotrophic with colimitation of primary production by phosphorus (P) and $\mathrm{N}$ availability [Wurtsbaugh et al., 1997].

\section{Methods}

\subsection{Sample Collection and Chemical Analysis}

[12] To evaluate the temporal patterns of DOM characteristics in subalpine stream-lake systems, we collected stream water samples at gauging stations located at inflows and outflows of seven lakes every 2-3 days, starting on 8 May 2008 and continued throughout the peak of the 2008 snowmelt hydrograph in late May. Following peak snowmelt, we sampled the seven inflows and outflows weekly through late August, and monthly through October. Additionally, in 2007 we sampled the inflows and outflows of four lakes (ALT, BT, PET, and ST) weekly following spring snowmelt through the fall. DOM characteristics were evaluated as DOC concentration, DOC: dissolved organic nitrogen (DON) ratio, and DOC specific ultraviolet absorbance ( $\left.\mathrm{SUVA}_{254}\right)$.

[13] We filtered replicate stream water samples through ashed $0.7 \mu \mathrm{m}$ glass-fiber filters (Whatman GF/F, Maidstone, United Kingdom). Samples for analysis of DOC concentra- tion and $\mathrm{SUVA}_{254}$ were acidified with $\mathrm{HCl}$ to a $\mathrm{pH}<2$ and stored in the dark until analysis, while filtered stream water samples for DON were frozen until analysis.

[14] We measured DOC concentrations on an Oceanography International Total Organic Carbon analyzer (OI Corporation model 700, College Station, Texas) using wet persulfate oxidation [Menzel and Vacarro, 1964]. DON was measured as total dissolved $\mathrm{N}$ (TDN) [Valderrama, 1981] minus dissolved inorganic $\mathrm{N}\left(\mathrm{NO}_{3}^{-}\right.$and $\left.\mathrm{NH}_{4}^{+}\right)$. We measured $\mathrm{NO}_{3}-\mathrm{N}$ by colorimetric analysis via cadmium reduction on an automated analyzer (Astoria Pacific International, Portland, Oregon). We measured $\mathrm{NH}_{4}-\mathrm{N}$ concentrations for a subset of samples using the phenol-hypochlorite colorimetric method [Solórzano, 1969] and found $\mathrm{NH}_{4}-\mathrm{N}$ concentrations to be near or below the detection limit $\left(\sim 1 \mu \mathrm{g} \mathrm{N} \mathrm{L}^{-1}\right)$. Therefore, $\mathrm{NH}_{4}-\mathrm{N}$ was considered to be $0 \mu \mathrm{g} \mathrm{N} \mathrm{L}^{-1}$ in the calculation of DON.

[15] We measured UV absorbance using a $1 \mathrm{~cm}$ path length quartz cell on a Genesys $10 \mathrm{UV}$ spectrophotometer (Thermo Fisher Scientific, Waltham, Massachusetts) at $254 \mathrm{~nm}$ using acidified double-deionized (DDI) water as a blank [Weishaar et al., 2003]. We then calculated $\mathrm{SUVA}_{254}$ by dividing the $\mathrm{UV}$ absorbance at $254 \mathrm{~nm}$ by the respective DOC concentration and report data as $\mathrm{L} \mathrm{mg} \mathrm{C}^{-1} \mathrm{~m}^{-1}$. High SUVA values indicate dominance by aromatic compounds [Westerhoff et al., 1999] that are less bioavailable than other DOC components [Marschner and Kalbitz, 2003].

\subsection{Hydrologic Measurements and Watershed Characteristics}

[16] We measured stream discharge (Q) weekly, using an electromagnetic flowmeter and topsetting wading rod (Flo-mate 2000, Marsh-McBirney Inc., Frederick, Maryland). Stream stage was recorded at hourly intervals using capacitance rods (Tru-Track, Inc., Christchurch, New Zealand) at all lake inflows and outflows, except for YB, which was instrumented with pressure transducers (Global Water Instrumentation, Inc., Gold River, California). These data were collected from April 2007 through October 2008 for ALT, BT, PET and ST inflows and outflows, while HR, LRF, and YB inflow and outflow stage was recorded from April 2008 through October 2008. We developed stream stage-discharge 
relationships and used the curves to estimate continuous stream discharge for the period of record.

[17] Because of ice-damaged stage recorders, discharge data was unavailable for ALT inflow and outflow from 1 January28 May 2008 and PET inflow and outflow from 31 January29 May 2008. To estimate the missing ALT inflow and outflow discharge, we regressed data from 1 October31 December 2007 and 30 May-22 September 2008 against the respective discharges for Stanley Lake. For PET Lake inflow and outflow, we regressed data from 1 October 2007-30 January 2008 and 30 May-22 September 2008 against ST inflow and outflow data to estimate the missing PET discharge. In order to reduce the weight of base flow correlations on the regression analysis and more accurately predict high flows in ALT and PET watersheds, we developed two regressions for each watershed, with one regression representing Stanley Lake outflow discharge $<1000 \mathrm{~L} / \mathrm{s}^{-1}$ and the other $>1000 \mathrm{~L} / \mathrm{s}^{-1}$ (Figure 2). The $\mathrm{R}^{2}$ was above 0.83 for all of these regressions.

[18] Lake volumes for Bull Trout, Hell Roaring and Little Redfish Lake were measured by taking a minimum of 125 depth soundings with a handheld echosounder and 60 lake perimeter locations that were localized with a global positioning system. Depth contour maps were made with SYSTAT plotting software, areas between contours were measured, and a hypsographic curve was drawn relating depth to area. This curve was then integrated to determine lake volumes. Volumes for the remaining study lakes were taken from work by Budy et al. [1995], who calculated the volumes in a similar manner.

[19] Watershed area was calculated using the multiwatershed delineation tool (MWD) from a $30 \mathrm{~m}$ digital elevation model (http://seamless.usgs.gov/) (Table 1). Lake areas and stream lengths were calculated from digital hydrography layers (National Hydrology Data set, 1:100,000) using ARC/ INFO (Environmental Systems Research Institute, Inc., Redlands, California). Lake area in the Sawtooth Mountains is highly correlated with lake volume measured bathymetrically. The volume of lakes in the surrounding watershed (i.e., not our immediate study lakes) were not calculated using hypsographic curves but using a lake area-volume log-log regression developed from 12 lakes in the Sawtooth Mountains with areas ranging from $0.04-6.15 \mathrm{~km}^{2}$ following (W. Wurtsbaugh, unpublished data, 2008; $\mathrm{R}^{2}=$ $0.995, p<0.0001)$ :

$$
\text { Volume }=0.0175 * \text { Area }^{1.517} \text {, }
$$

where volume is in units of $\mathrm{km}^{3}$ and area is in $\mathrm{km}^{2}$.

[20] For base flow conditions, assuming lake hydrologic steady state and complete mixing, maximum water residence time for the seven lakes was calculated as:

$$
R_{t}=V / Q
$$

where $R_{t}$ is the maximum water residence time (years) within the lake, $\mathrm{V}$ is lake volume $\left(\mathrm{m}^{3}\right)$ and $\mathrm{Q}$ is mean outflow discharge $\left(\mathrm{m}^{3} \mathrm{yr}^{-1}\right)$ during base flow (Table 1).

\subsection{Analysis of Temporal Variability and Patterns}

[21] First, we assessed if our sampling design was sufficient to characterize temporal patterns in DOM characteristics by evaluating mean-variance relationships, as log-log plots [Cattaneo and Prairie, 1995]. Mean-variance plots provide insight into the magnitude of temporal variation relative to the mean. Following the work of Cattaneo and Prairie [1995], a slope of two indicates constant variability relative to means (i.e., constant coefficients of variation (CVs)). Slopes greater than two indicate increasing variability with increasing means, and signify a need for more frequent samples to capture this variability. In the latter case, we estimated the sample size required to accurately capture the temporal variability using standard techniques presented by Downing [1979].

\subsubsection{DOM Flushing and Intra-annual Buffering}

[22] To evaluate if lakes act to buffer DOC snowmelt flushing, we compared the timing at which the DOC center of mass (i.e., $50 \%$ of the cumulative mass) was exported during the 2008 water year for the seven study lake inflows and outflows [Hodgkins et al., 2003; Sebestyen et al., 2008]. If lakes buffer snowmelt flushing and stream temporal variability, then the lake outflow DOC center of mass export should occur after the inflow center of mass export and DOM temporal variation (measured as CV) should be less in lake outflows than lake inflows. Additionally, we evaluated the timing of DOC flushing relative to changes in discharge in inflows and outflows by plotting DOC concentration and stream discharge from April to October 2008. These plots provide visual analysis of concentrations during the rising and falling limb of the hydrograph, with greater concentrations on the rising limb than the falling limb indicating greater hysteresis, which is typical of a slowly renewed source pool (e.g., terrestrial organic carbon in mountain ecosystems). If lakes buffer snowmelt flushing of terrestrial DOM and provide an additional source of DOM, then lake inflows should exhibit greater hysteresis than outflows.

[23] DOM temporal variability across the sampling season was assessed by calculating means and coefficients of variation for DOC concentration, $\mathrm{SUVA}_{254}$, and DOC:DON ratio from April to October 2008, and CVs were compared between all lake inflows and outflows using analysis of variance (ANOVA, JMP 7.0.1, SAS Institute, Cary, NC). Alpha value was set to 0.05 . To evaluate the relationships between the temporal variability of DOM characteristics and potential environmental drivers we calculated Pearson correlation coefficients between CVs and geographic information system (GIS)-derived watershed characteristics (e.g., percent upstream lake area, percent barren area, stream distance to the closest upstream lake, volume of the closest upstream lake, study lake volume, study lake: watershed area, and combined water residence time in upstream lakes; Table 1), which may impact temporal DOM variability.

\subsubsection{Equality of Temporal Patterns}

[24] Nonparametric analysis of covariance (ANCOVA) was conducted to asses whether or not temporal patterns of DOM characteristics were the same across lake inflow and outflow pairs during the 2008 sampling season [Young and Bowman, 1995]. The grouping variable was inflow versus outflow and time was the covariate. Models were fit using the sm package (version 2.2-3; software available at http://www. cran.r-project.org/) in R version 2.9.1 (R Development Core Team, Vienna, Austria). This model uses cross validation to select the best smoothing parameter $(h)$ for each pair (i.e., lake inflow and outflow) of regression curves. Adjusting 


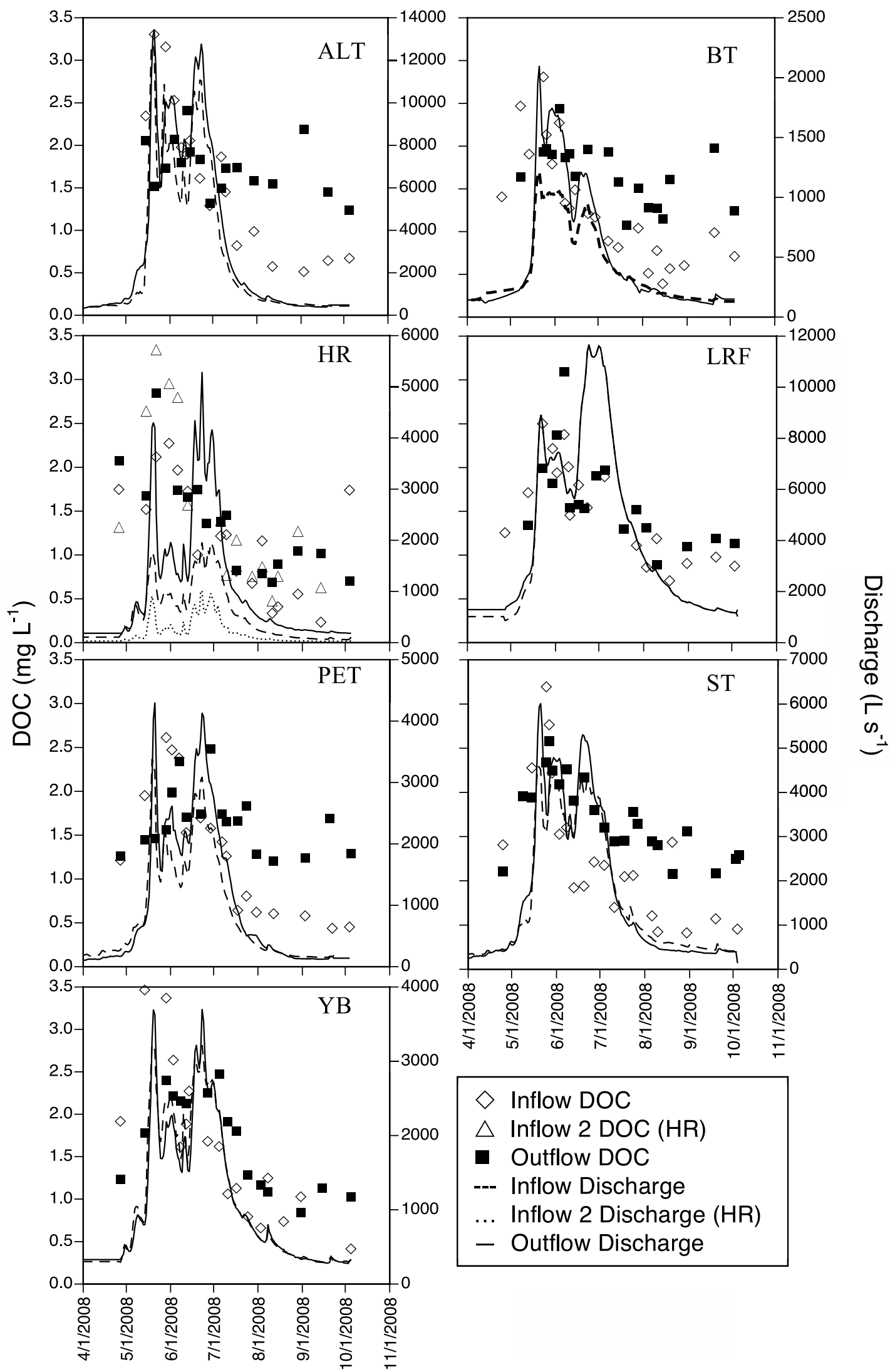

Figure 2. Late April to early October 2008 hydrographs and DOC concentrations for seven lake inflows and outflows of the Sawtooth Mountain lake district. Open symbols indicate inflow DOC concentration and closed squares indicate outflow DOC concentrations. 
Table 2. Day of the Year When $50 \%$ of the Total Annual DOC Mass Had Been Exported During the 2008 Water Year for Seven Lake Inflows and Outflows in the Sawtooth Mountains, Central Idaho

\begin{tabular}{cccc}
\hline Watershed ID & Inflow DOC & Outflow DOC & $\begin{array}{c}\text { Outflow - Inflow } \\
\text { DOC Lag }\end{array}$ \\
\hline ALT & 154 & 160 & 6 \\
BT & 150 & 153 & 3 \\
HR1 & 156 & 161 & 5 \\
HR2 & 158 & 161 & 3 \\
LRF & 166 & 165 & -1 \\
PET & 157 & 168 & 11 \\
ST & 151 & 156 & 5 \\
YB & 152 & 163 & 11 \\
\hline
\end{tabular}

${ }^{a}$ Outflow - Inflow DOC Lag is the difference between day the outflow and inflow DOC Center of Mass occurred.

$h$ did not significantly alter the results of the nonparametric ANCOVA. The model compares curves to a reference band, which indicates the acceptance region for the null hypothesis (that is, the temporal pattern in inflow and outflow are the same). The width of the reference band is directly related to the difference between the actual data and the modeled curve. For example, when the actual data points do not fit the modeled curve well, the width of the reference band increases, and thus there is a larger probability of accepting the null hypothesis. ANCOVA alpha was 0.05 .

\subsection{Annual Export Estimates}

[25] To evaluate if lakes alter DOC export, we compared snowmelt, base flow, and total annual DOC loads for the seven lake inflows and outflows. We modeled DOC concentrations between sampling events as the mean DOC concentration of the two samples spanning each modeled period. Daily flux, $\mathrm{F}_{\mathrm{d}}$, of DOC $\left(\mathrm{kg} \mathrm{C} \mathrm{d}^{-1}\right)$ was calculated as:

$$
F_{d}=Q^{*}[D O C]
$$

where $\mathrm{Q}$ is mean daily discharge $\left(\mathrm{L} \mathrm{d}^{-1}\right)$ and $[\mathrm{DOC}]$ is the DOC concentration $\left(\mathrm{kg} \mathrm{C} \mathrm{L}^{-1}\right)$. During high flows $\left(>1200 \mathrm{~L} \mathrm{~s}^{-1}\right)$ in some watersheds, we were unable to account for all of the inflow water (Figure 2); thus lake inflow DOC loads were calculated using outflow discharge. This approach assumes that all of the unmeasured water entering the lake was from surface or groundwater flows with similar DOC concentrations as the inflow. A limited number of measurements of DOC concentrations from groundwater springs within Bull Trout Watershed in June $(0.56 \pm 0.085 \mathrm{mg} \mathrm{C/L})$ and July $(0.61 \pm 0.088 \mathrm{mg} \mathrm{C} / \mathrm{L})$ were low, and may have diluted the inflow water. Consequently, our assumption that the unmeasured water had equal DOC concentrations as that in the stream channel may result in an overestimation of the inflow DOC load to the lake.

[26] Annual DOC load for all inflows and outflows was calculated as the sum of the daily DOC flux for the 2008 water year (1 October 2007-30 September 2008). April (presnowmelt) 2008 and October 2008 discharge for HR, $\mathrm{LRF}$, and YB were similar, and we used the mean to predict discharge from October 2007-April 2008. Mean base flow DOC concentrations was used as an estimate of DOC concentration from October 2007-April 2008. Annual DOC export from each watershed, above and below the lakes was calculated by dividing the annual DOC load by the respective watershed area (Table 1), where the outflow watershed area represented the entire drainage area and the inflow watershed area was the outflow watershed area minus the lake area. This approach allows comparison across our seven study watersheds, which differ considerably in watershed areas and inflow DOC concentrations. For the 2008 water year, DOC export for inflows and outflows was calculated, as above, for the time period of snowmelt and base flow. Snowmelt and base flow time periods were determined by calculating the second derivative of the outflow hydrograph to identify the day upon which the maximum change in concavity occurred. Snowmelt timing was similar in our 7 study watersheds: ALT (30 April-23 July), BT (3 May-2 August), HR (2 May25 July), LRF (3 May-27 July), PET (2 May-2 August), ST (2 May-26 July), YB (4 May-2 August).

\subsection{DOC Production}

[27] To evaluate if lakes can act as a source of DOC in mountain fluvial networks mean base flow DOC concentrations in the stream inflows and outflows were compared using ANOVA. Four lake inflows and outflows were compared in 2007 and seven in 2008.

[28] In order to evaluate the seasonal role of mountain lakes throughout a sampling season, we calculated the percentage (\%) of in-lake DOC production from April-October 2008. The percentage of in-lake DOC production was calculated as:

$\%$ DOC production $=\left[\left(\mathrm{F}_{\mathrm{d}(\text { outflow })}\right)-\left(\mathrm{F}_{\mathrm{d}(\text { inflow })}\right)\right] / \mathrm{F}_{\mathrm{d}(\text { inflow })} * 100$.

[29] Negative values signify that the lake was acting as a DOC sink, while positive values signify the lake was acting as a DOC source. To examine relationships between in-lake DOC production and watershed characteristics, correlation coefficients were calculated between maximum DOC production values and watershed variables (Table 1).

[30] Error associated with the percentage of in-lake DOC production was calculated as the fractional error associated with discharge measurements and DOC analytical measurements. We ascribe a $10 \%$ error to the discharge measurements [Sauer and Meyer, 1992]. We calculate maximum fractional error of DOC analytical measurements as the average DOC uncertainties observed in replicate samples $\left(0.0065 \mathrm{mg} \mathrm{C} \mathrm{L}^{-1}\right)$, divided by the minimum DOC values observed in our sites $\left(0.5 \mathrm{mg} \mathrm{C} \mathrm{L}^{-1}\right)$. We rearrange equation (4) as

$$
\% \text { DOC production }=\left(\mathrm{F}_{\mathrm{d}(\text { outflow })} / \mathrm{F}_{\mathrm{d}(\text { inflow })}-1\right) * 100
$$

[31] Following Taylor [1997], we calculate the uncertainty associated with the $\%$ DOC production calculations as:

$$
\frac{\delta P}{|P|}=\sqrt{\left(\frac{\delta C_{o}}{C_{o}}\right)^{2}+\left(\frac{\delta Q_{o}}{Q_{o}}\right)^{2}+\left(\frac{\delta C_{i}}{C_{i}}\right)^{2}+\left(\frac{\delta Q_{i}}{Q_{i}}\right)^{2}}
$$

where $\delta$ is the uncertainty associated with each variable, $\mathrm{P}$ is the percent $\mathrm{DOC}$ production, $\mathrm{C}_{\mathrm{o}}$ is the outflow DOC con- 


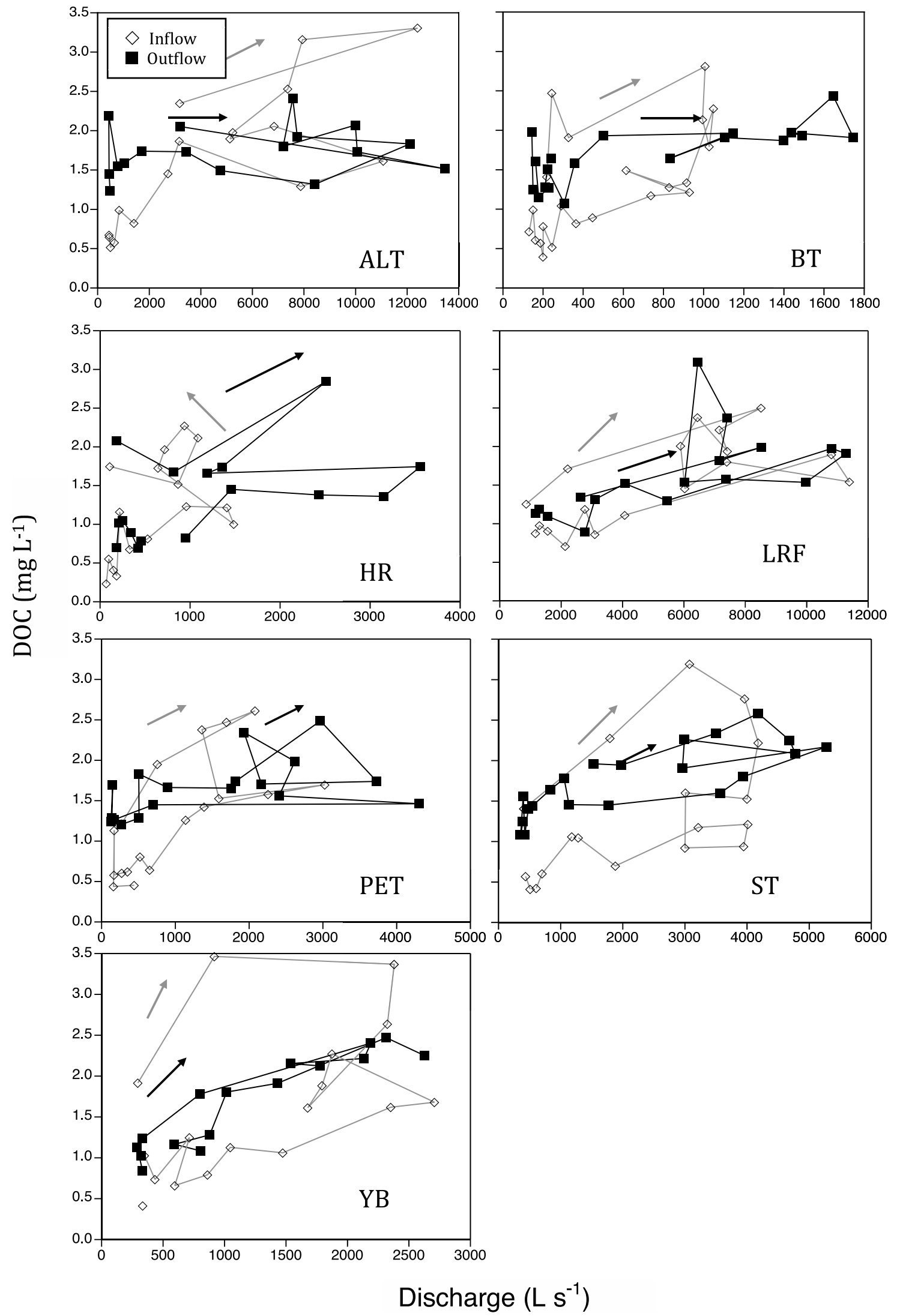

Figure 3. Hysteresis plots of DOC concentration versus discharge for seven study lake inflows and outflows in the Sawtooth Mountain lake district from April to October 2008. Hell Roaring Lake has two inflows, but only HR1 is plotted. 
Table 3. Means and Coefficients of Variation (CV, \%) for DOM Concentration (DOC) and Characteristics for Seven Lake Inflows and Outflows of the Sawtooth Mountain Lake District in Central Idaho, Throughout the 2008 Sampling Season From Early Spring (Presnowmelt) to Early Fall

\begin{tabular}{|c|c|c|c|c|c|c|c|c|}
\hline \multirow[b]{2}{*}{ Watershed } & \multirow[b]{2}{*}{ Position } & \multirow[b]{2}{*}{$n^{\mathrm{b}}$} & \multicolumn{2}{|c|}{$\mathrm{DOC}^{\mathrm{a}}$} & \multicolumn{2}{|c|}{ SUVA } & \multicolumn{2}{|c|}{ DOC:DON } \\
\hline & & & Mean & $\mathrm{CV}$ & Mean & $\mathrm{CV}$ & Mean & $\mathrm{CV}$ \\
\hline ALT & Inflow & 18 & 1.63 & 54.0 & 1.89 & 31.1 & 35.6 & 40.0 \\
\hline ALT & Outflow & 18 & 1.74 & 18.1 & 1.43 & 24.6 & 44.3 & \\
\hline BT & Inflow & 24 & 1.31 & 50.6 & 1.61 & 40.5 & 33.0 & \\
\hline BT & Outflow & 19 & 1.68 & 21.3 & 2.18 & 24.5 & 24.0 & \\
\hline HR & Inflow 1 & 18 & 1.24 & 52.8 & 1.34 & 86.6 & 68.2 & \\
\hline HR & Inflow 2 & 18 & 1.51 & 62.5 & 1.56 & 62.8 & 75.1 & 41 \\
\hline HR & Outflow & 18 & 1.37 & 42.8 & 1.36 & 40.5 & 62.6 & 42 \\
\hline LRF & Inflow & 20 & 1.52 & 37.1 & 1.18 & 47.8 & 62.6 & 42 \\
\hline LRF & Outflow & 21 & 1.63 & 32.2 & 1.13 & 46.9 & 62.4 & 34 \\
\hline PET & Inflow & 17 & 1.36 & 52.1 & 1.57 & 44.9 & 47.4 & \\
\hline PET & Outflow & 20 & 1.65 & 21.9 & 1.13 & 29.8 & 29.8 & \\
\hline ST & Inflow & 22 & 1.29 & 62.4 & 1.58 & 32.1 & 31.2 & \\
\hline ST & Outflow & 23 & 1.70 & 26.2 & 1.71 & 21.4 & 28.1 & \\
\hline YB & Inflow & 17 & 1.64 & 53.5 & 1.74 & 36.3 & 42.8 & \\
\hline YB & Outflow & 18 & 1.68 & 33.2 & 1.31 & 18.3 & 43.5 & 33.8 \\
\hline
\end{tabular}

${ }^{\mathrm{a}} \mathrm{DOC}$ is $\mathrm{mg} \mathrm{C} \mathrm{L} \mathrm{L}^{-1}$ and SUVA is $\mathrm{L} \mathrm{mg} \mathrm{C}^{-1} \mathrm{~m}^{-1}$.

${ }^{\mathrm{b}}$ Number of sampling dates.

centration, $Q_{0}$ is the outflow discharge measurement, $C_{i}$ is the inflow DOC concentration, and $\mathrm{Q}_{i}$ is the inflow discharge measurement.

\section{Results}

\subsection{Temporal Variability and Patterns}

[32] We found no significant mean-variance relationship for DOC concentration over time across our fifteen study streams $\left(\mathrm{F}_{1,13}=2.28, \mathrm{R}^{2}=0.15, p=0.16\right)$ or $\mathrm{SUVA}_{254}$ $\left(\mathrm{F}_{1,13}=0.063, \mathrm{R}^{2}=0.005, p=0.81\right)$, as evaluated by loglog plots, which indicated a consistent variance relative to the respective means and adequate sample size. In contrast, we found a strong positive relationship between the means and temporal variances of DOC:DON ratios across the fifteen streams $\left(\mathrm{R}^{2}=0.80, \mathrm{~F}_{1,13}=51.70, p<0.0001\right)$, which indicated an increasing $\mathrm{CV}$ with increasing mean. This strong positive relationship for DOC:DON was statistically indistinguishable for inflows and outflows, when the two were graphed separately (ANCOVA, $p=0.78$ ). Despite these strong relationships for DOC:DON ratios in inflows and outflows, we did not observe strong mean-variance relationships for DOC or DON alone. This strong positive relationship between mean and variance of DOC:DON ratios indicated a need for more frequent samples in order to have adequately captured the large temporal variability. We estimate that 1.8 times the number of samples we analyzed would have been required to adequately assess temporal variation in DOC:DON. Thus, DOC:DON ratio results will be evaluated in terms of the magnitude of variability in these systems but will not be evaluated for temporal patterns and landscape controls. We return to the implications of this variability in the discussion.

\subsubsection{DOM Flushing and Intra-annual Buffering}

[33] Our results show that lakes alter the timing of DOC export during snowmelt. Timing of peak daily discharge was similar between lake inflow and outflow pairs, with 60
Table 4. Correlation Coefficients $(r)$ and Significance $(p)$ Between DOM Coefficients of Variation (CV) and Watershed Variables During the 2008 Sampling Season ${ }^{\mathrm{a}}$

\begin{tabular}{|c|c|c|c|c|c|}
\hline & \multirow[b]{2}{*}{$n^{\mathrm{d}}$} & \multicolumn{2}{|c|}{$\mathrm{DOC}$} & \multicolumn{2}{|c|}{ SUVA } \\
\hline & & $r$ & $p$ & $r$ & $p$ \\
\hline$\%$ Upstream lake area & 15 & -0.578 & 0.024 & -0.093 & 0.742 \\
\hline$\%$ Barren area & 15 & 0.406 & 0.133 & 0.653 & 0.008 \\
\hline$\%$ Vegetated area & 15 & -0.342 & 0.267 & -0.677 & 0.006 \\
\hline $\begin{array}{l}\text { Distance to closest } \\
\text { upstream lake }\end{array}$ & 5 & -0.273 & 0.657 & 0.008 & 0.990 \\
\hline $\begin{array}{l}\text { Volume of closest } \\
\text { upstream lake }\end{array}$ & 5 & -0.890 & 0.043 & -0.219 & 0.724 \\
\hline Study lake volume ${ }^{c}$ & 7 & -0.623 & 0.135 & -0.270 & 0.559 \\
\hline $\begin{array}{l}\text { Study lake: Watershed } \\
\text { area }^{c}\end{array}$ & 7 & -0.574 & 0.178 & -0.408 & 0.363 \\
\hline
\end{tabular}

${ }^{\mathrm{a}} \mathrm{DOC}$ is $\mathrm{mg} \mathrm{C} \mathrm{L}^{-1}$ and SUVA is $\mathrm{L} \mathrm{mg} \mathrm{C}^{-1} \mathrm{~m}^{-1}$. Significant correlations are boldface.

${ }^{\mathrm{b}}$ Analyzed only with study lake inflows.

${ }^{c}$ Analyzed only with study lake outflows.

${ }^{\mathrm{d}}$ Number of streams included in the analysis.

$80 \%$ of water export during snowmelt (Figure 2 ). However, the DOC center of mass occurred, on average, $5.4+1.4(\mathrm{SE})$ days earlier in seven lake inflows relative to their respective outflows (Table 2). Additionally, peak DOC concentrations were higher in lake inflows than lake outflows (Figure 2). After snowmelt flushing in June, inflow DOC concentrations decreased to presnowmelt values and ranged from 0.5 $1.0 \mathrm{mg} \mathrm{C} \mathrm{L}{ }^{-1}$. In contrast, outflow DOC concentrations remained elevated after snowmelt and ranged from 1.0 to $2.0 \mathrm{mg} \mathrm{C} \mathrm{L}^{-1}$ (Figure 2).

[34] In addition to a lag in DOC export in outflows relative to inflows, we observed greater DOC hysteresis in lake inflows than in lake outflows (that is, lake inflow DOC concentrations increased at a faster rate with increasing discharge). Six of the seven lake inflows showed clockwise hysteresis, with rapid increases in DOC concentration on the ascending limb of the hydrograph and lower concentrations on the descending limb of the hydrograph (Figure 3). The hydrograph in all watersheds except BT was bimodal (Figure 2), with the first peak in discharge associated with higher DOC concentrations (Figure 3). The only lake inflow that did not exhibit hysteresis was LRF, which is directly downstream of a large $\left(6 \mathrm{~km}^{2}\right)$ lake (Figure 1 and Table 1$)$.

Table 5. Nonparametric ANCOVA Results Comparing Equality of Temporal Patterns of DOM Characteristics Between Seven Lake Inflows and Outflows of the Sawtooth Mountains, Central Idaho, from May to October $2008^{\mathrm{a}}$

\begin{tabular}{lccccc}
\hline & \multicolumn{2}{c}{ DOC } & & \multicolumn{2}{c}{ SUVA } \\
\cline { 2 - 3 } \cline { 5 - 6 } Watershed & $h$ & $p$ & & $h$ & $p$ \\
\hline ALT & 25.0 & $\mathbf{0 . 0 1 4}$ & 30.6 & $\mathbf{0 . 0 1 8}$ \\
BT & 20.3 & $\mathbf{0 . 0 1 3}$ & 19.5 & $\mathbf{0 . 0 1 2}$ \\
HR1 & 31.8 & 0.140 & 31.8 & $\mathbf{0 . 0 3 8}$ \\
HR2 & 12.7 & 0.224 & 12.4 & $\mathbf{0 . 0 5 0}$ \\
LRF & 20.0 & 0.776 & 7.8 & 0.606 \\
PET & 28.7 & $\mathbf{0 . 0 1 7}$ & 15.0 & $\mathbf{0 . 0 4 8}$ \\
ST & 15.6 & $\mathbf{0 . 0 0 9}$ & 21.2 & 0.268 \\
YB & 31.3 & $\mathbf{0 . 0 3 0}$ & 25.0 & 0.176 \\
\hline
\end{tabular}

${ }^{\mathrm{a}} \mathrm{HR} 1$ and HR2 represent two different inflows to HR Lake; $h$ is the smoothing parameter. $p$-value $<0.05$ indicates inflow and outflows patterns are not equal. Significant differences are boldface. 

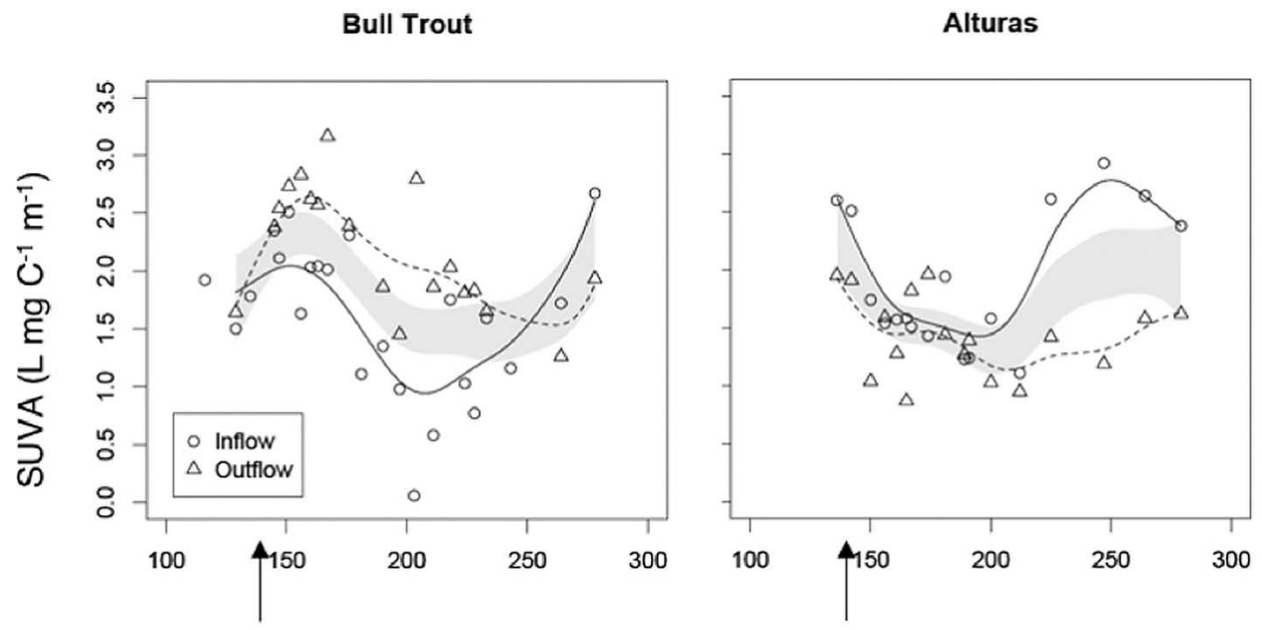

Day of Year

Figure 4. Relationship between time of year and DOC-specific ultraviolet absorbance $\left(\mathrm{SUVA}_{254}\right)$, in the inflows and outflows of (left) Bull Trout and (right) Alturas Lakes. SUVA 254 for stream inflows (circles) and outflows (triangles) are shown and the lines were fit by nonparametric analysis of covariance. For both plots, inflow (solid) and outflow (dashed) curves are not equal, $p<0.05$. Arrows indicate that the time of peak snowmelt discharge occurred between day of year 140 and 143 .

In contrast to lake inflows, DOC concentration in lake outflows did not increase as rapidly on the ascending limb of the hydrograph. Instead, lake outflow DOC concentrations tended to increase on the descending limb of the hydrograph (Figure 3).

[35] DOM in lake inflows was more variable, as measured by coefficients of variation, than in lake outflows (Table 3 ). Throughout the 2008 sampling season, inflow CVs were 1.9 times greater for DOC concentration $\left(\mathrm{F}_{1,13}=34.64\right.$, $p<0.0001), 1.6$ times greater for $\mathrm{SUVA}_{254}$ values $\left(\mathrm{F}_{1,13}=\right.$ $5.24, p=0.039)$ and 1.4 times greater for DOC:DON ratio values $\left(\mathrm{F}_{1,13}=13.72, p=0.0026\right.$; Table 3$)$ than outflow CVs.

[36] DOM temporal variability was related to watershed attributes. For both the inflows and outflows, the CVs for DOC concentration were significantly negatively correlated with the percentage of the upstream watershed covered by lakes $(r=-0.578, p=0.024)$. For example, in the Stanley watershed with only $0.46 \%$ upstream lakes, the CV for DOC concentration was 62.4 , whereas in the Pettit watershed with
$2.44 \%$ upstream lakes, the CV was only 52.5. For inflows alone, the CVs of DOC concentrations were negatively correlated with the area of the closest upstream lake $(r=-0.900$, $p=0.037$; Table 4). CVs for $\mathrm{SUVA}_{254}$ were positively correlated to the percentage of upstream barren area $(r=0.653$, $p=0.008)$ and negatively correlated to the $\%$ of upstream area covered by vegetation $(r=-0.677, p=0.006)$.

\subsubsection{Equality of DOM Temporal Patterns}

[37] Temporal patterns of DOC concentration differed significantly between inflows and outflows for 5 of the 7 study watersheds (ANCOVA, $p<0.03$; Table 5). This resulted from higher DOC peaks in the inflow during snowmelt and higher DOC concentrations in outflows during base flow (Figure 2).

[38] Likewise, $\mathrm{SUVA}_{254}$ variability was greater in inflows than outflows (Figure 4 and Table 3 ). SUVA $_{254}$ values presnowmelt in all study watersheds were approximately 1.5-2.0 L mg C $\mathrm{m}^{-1}$. During peak snowmelt (day of the year 140-142), SUVA $_{254}$ values were approximately 2.5-3.0 $\mathrm{L} \mathrm{mg} \mathrm{C} \mathrm{m}^{-1} \mathrm{~m}^{-1}$ and were the highest values (i.e.,

Table 6. DOC Export $\left(\mathrm{kg} \mathrm{C} \mathrm{ha}^{-1}\right)$ During Snowmelt, Base Flow and Total Annual for Seven Lake Inflows and Outflows of the Sawtooth Mountains, Central Idaho During the 2008 Water Year, 1 October 2007-30 September 2008

\begin{tabular}{|c|c|c|c|c|c|c|c|c|}
\hline \multirow[b]{3}{*}{$\mathrm{WS}^{\mathrm{a}}$} & \multicolumn{4}{|c|}{ Inflow } & \multicolumn{4}{|c|}{ Outflow } \\
\hline & \multicolumn{3}{|c|}{$\mathrm{kg} \mathrm{C} \mathrm{ha}^{-1}$} & \multirow{2}{*}{$\begin{array}{l}\text { \% Snowmelt } \\
\text { DOC Export }\end{array}$} & \multicolumn{3}{|c|}{$\mathrm{kg} \mathrm{C} \mathrm{ha}^{-1}$} & \multirow{2}{*}{$\begin{array}{l}\text { \% Snowmelt } \\
\text { DOC Export }\end{array}$} \\
\hline & Snowmelt & Base flow & Total & & Snowmelt & Base flow & Total & \\
\hline ALT & 13.9 & 1.3 & 15.2 & 91.3 & 12.3 & 2.8 & 15.1 & 81.3 \\
\hline BT & 9.4 & 2.2 & 11.6 & 81.2 & 10.6 & 3.7 & 14.3 & 74.1 \\
\hline HR & 11.8 & 1.7 & 13.5 & 87.3 & 11.1 & 2.7 & 13.8 & 80.5 \\
\hline LRF & 8.3 & 3.1 & 11.4 & 73.0 & 8.1 & 3.5 & 11.6 & 70.1 \\
\hline PET & 10.4 & 1.2 & 11.6 & 89.3 & 10.0 & 2.4 & 12.4 & 80.6 \\
\hline ST & 9.1 & 2.3 & 11.4 & 80.0 & 11.3 & 3.7 & 15.3 & 75.7 \\
\hline YB & 9.4 & 2.6 & 12.0 & 78.5 & 10.1 & 2.9 & 13.0 & 77.7 \\
\hline
\end{tabular}

${ }^{\mathrm{a}}$ WS is Watershed. Snowmelt occurred in ALT (30 April-23 July), BT (3 May-2 August), HR (2 May-25 July), LRF (3 May-27 July), PET (2 May2 August), ST (2 May-26 July), and YB (4 May-2 August).

${ }^{\mathrm{b}}$ Percent snowmelt export is the percent of annual DOC exported during snowmelt flows. 
greatest aromatic compounds) observed throughout the sampling season. Following peak snowmelt, $\mathrm{SUVA}_{254}$ values decreased to $0.5-1.0 \mathrm{~L} \mathrm{mg} \mathrm{C}^{-1} \mathrm{~m}^{-1}$ in all seven lake inflows and outflows. In mid July, inflow SUVA 254 values began increasing toward presnowmelt values. Conversely, outflow SUVA values remained relatively low throughout the summer until mid September (approximate day of the year 250), when the $\mathrm{SUVA}_{254}$ values increased toward presnowmelt values (Figure 4; Bull Trout and Alturas inflow and outflow data shown). Bull Trout and Stanley Lake had the only lake outflow that exhibited higher SUVA values then its respective inflow (Table 3).

\subsection{Lakes as a DOC Source}

[39] Annual DOC exports ranged from $10.9-15.7 \mathrm{~kg} \mathrm{C} \mathrm{ha}^{-1}$ $\mathrm{yr}^{-1}$ for inflows and from 11.6-15.3 $\mathrm{kg} \mathrm{C} \mathrm{ha}^{-1} \mathrm{yr}^{-1}$ for outflows (Table 6). Annual export increased downstream of six (BT, HR, LRF, PET, ST and YB) of the seven study lakes. During snowmelt, inflows exported between $73-92 \%$ of their total annual DOC export to lakes, while lake outflows exported from $70-82 \%$ of the total annual DOC export. During base flow periods, DOC export was 1.2-2.4 times greater in lake outflows than their respective inflows (Table 6).

[40] Mean base flow DOC concentrations in 2008 were 1.7 times greater in the lake outflows than inflows $\left(\mathrm{F}_{1,12}=\right.$ $18.32 ; p=0.0011$; Figure 5) for the seven watersheds. During 2008 base flow, lake outflow DOC concentrations were significantly greater than inflows in ALT $\left(\mathrm{F}_{1,8}=\right.$ $26.8136, p=0.0008)$, BT $\left(\mathrm{F}_{1,11}=29.2093, p=0.0002\right)$, LRF $\left(\mathrm{F}_{1,11}=5.5135, p=0.0386\right)$, PET $\left(\mathrm{F}_{1,7}=38.6448\right.$, $p=0.0004)$, and ST $\left(\mathrm{F}_{1,9}=64.9571, p<0.0001\right)$ and marginally significant in $\mathrm{YB}\left(\mathrm{F}_{1,10}=4.263, p=0.066\right)$ and $\operatorname{HR}\left(\mathrm{F}_{1,10}=3.8321, p=0.0788\right.$; Figure 5). Similarly, in 2007 outflow DOC concentrations were two times greater than

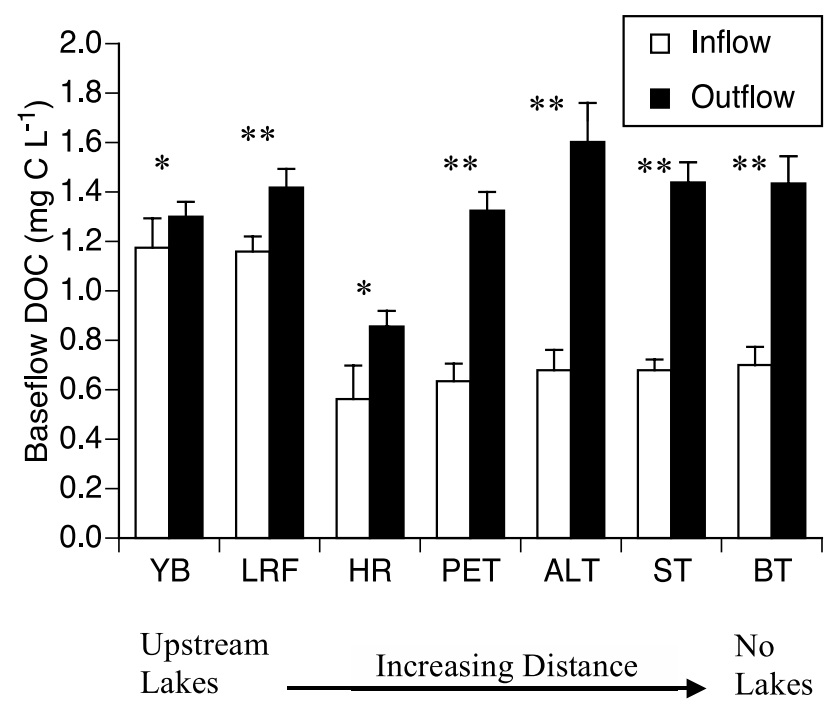

Figure 5. Mean (+SE) DOC concentrations during 2008 base flow conditions (August-October) for seven lake inflows (white bars) and outflows (black bars) in the Sawtooth Mountains, central Idaho. Lakes are plotted in order of increasing distance to an upstream lake. Double asterisks indicate $p<0.04$. Single asterisk indicates $p<0.08$.

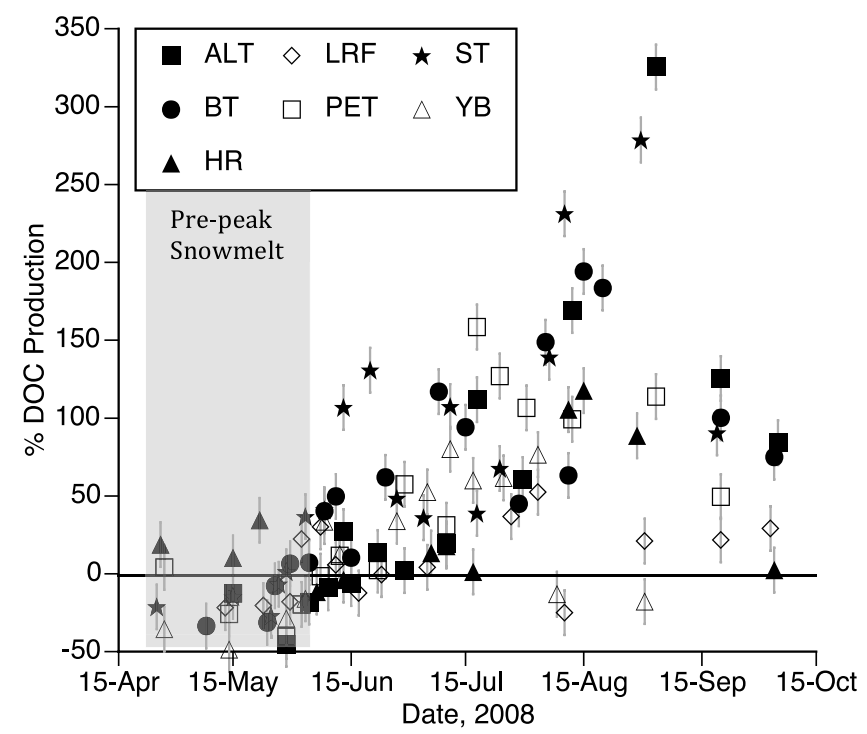

Figure 6. Percentage DOC production calculated as the difference in DOC concentration between each inflow and outflow pair relative to the respective inflow concentration for seven lakes in the Sawtooth Mountains, central Idaho, from April-October 2008. The error bars indicate the $14.3 \%$ uncertainty associated with the calculation.

inflows during base flow $\left(\mathrm{F}_{1,6}=17.66 ; p=0.0057\right)$ in all four study watersheds studied that year (ALT, BT, PET and ST).

[41] The percentage of in-lake DOC production varied temporally and spatially. From April through late May (prepeak snowmelt), the percentage of DOC production in all lakes was at or below 0 (Figure 6). Following spring snowmelt in late May/early June, the percentage of DOC production increased in all lakes, as the lakes became a source of DOC to outflow streams. The percentage of DOC production in LRF and YB had lower peaks $(<80 \%)$, which occurred in early August before they declined to $<50 \%$. Conversely, in the other five study lakes the percentage of DOC production peaked at $160-330 \%$ of inflow values in mid-late August before they declined (Figure 6). Maximum percentage of DOC production was negatively correlated with the percentage of total upstream lake area $\left(r=-0.77, \mathrm{~F}_{1,5}=7.26\right.$; $p=0.043)$ and the percentage of vegetation cover $(r=-0.78$, $\left.\mathrm{F}_{1,5}=7.96 ; p=0.037\right)$ and was not correlated to any other watershed characteristics. For example, in ALT watershed with $0.7 \%$ lake cover, maximum percentage of DOC production was $325.5 \%$, whereas in YB watershed with $3.2 \%$ lake cover, DOC production was only $80 \%$. Combined, these results show that lakes can store DOC during snowmelt and provide DOC to downstream locations during base flow.

\section{Discussion}

[42] Our results support the hypothesis that the presence of lakes within mountain stream networks can alter DOM dynamics. First, we showed that subalpine lakes can dampen the magnitude of the pulse of DOC in streams during snowmelt flushing and alter the timing of DOC export to downstream locations, ultimately decreasing the temporal variability of lake-outflow stream DOC concentration and characteristics compared to lake inflows. Second, 
we observed a seasonal shift in the role of mountain lakes on watershed DOC dynamics, as subalpine lakes switched from a DOC sink during springtime hydrologic flushing to a DOC source during summer base flow.

\subsection{DOM Temporal Variability and Patterns}

[43] Our results indicate that during spring snowmelt, lakes buffered outflows from DOM flushing. We observed a decline in the DOC temporal variability, the DOC response to snowmelt flushing (both the timing and the rate of increase), and the magnitude of DOC concentrations in the outflow relative to the inflow (Figures 2 and 3 and Table 2), signifying in-lake DOC retention during snowmelt. LRF inflow was the only lake inflow that did not exhibit a rapid increase in DOC concentration on the ascending limb of the snowmelt hydrograph (Figure 3 ) or a DOC lag (Table 2). This result is likely due to a large $\left(6 \mathrm{~km}^{2}\right)$ lake only $2.6 \mathrm{~km}$ upstream (Figure 1) causing LRF inflow to behave more like lake outflows. In contrast, lakes do not buffer the timing or magnitude of peak stream water discharge (Figure 2), consistent with data from Bull Trout presented by Arp et al. [2006]. The inability of lakes to buffer spring snowmelt flows is likely a result of low in-lake storage capacity as lake water levels rise [Arp et al., 2006]. These results indicate that while hydrologic factors have a large control on stream snowmelt DOC dynamics, in-lake biogeochemical factors also influence lake outflow DOC dynamics.

[44] The inflow DOC flushing responses observed in the Sawtooth Mountain lake district were similar to other snowmelt-dominated systems, where snowmelt represents a flushing of a finite terrestrial DOC source in soil pore water [Boyer et al., 1997; Brooks et al., 1999; Hood et al., 2003; Hornberger et al., 1994]. However, our results indicate that lakes can dampen this DOC flushing response in lake outflows. The ability of lakes to dampen this DOC pulse was variable across watersheds and is likely related to an interaction of many factors including controls on DOC pulse dynamics, such as hillslope connectivity [McGlynn and McDonnell, 2003], topography, elevation and patterns of snow accumulation and melting [Boyer et al., 1997; Hornberger et al., 1994], as well as controls on lake DOC dynamics, such as lake residence time [Arp et al., 2006] and in-lake microbial processing [Crump et al., 2003].

[45] Pace and Cole [2002] hypothesized that DOC may build up in lakes during times of ice cover due to a lack of light, and hence a lack of photodegradation. If this occurred in our study, we would have expected lake outflows to exhibit high DOC concentrations during spring snowmelt flushing. However, pre-ice-out DOC concentrations in outflows of our study lakes were not above base flow concentrations (Figure 2), and their peak snowmelt DOC concentrations were lower than inflows. The fact that we did not observe a buildup of DOC in lakes during ice cover may be a result of their oligotrophic nature, and hence low productivity [Budy et al., 1995].

[46] As expected, we observed significantly lower CVs for DOM concentrations and characteristics in lake outflows than inflows (Table 3). These results illustrate the ability of lakes to buffer stream DOM temporal variability. In contrast, Cattaneo and Prairie [1995] did not observe a dampening effect of lakes on lake outlet stream chemistry (DOC concentration was not included) in a low-gradient Canadian stream, which they attributed to the relatively small lake size $\left(0.03-5.29 \mathrm{~km}^{2}\right)$ and rapid flushing (not reported) of their study lakes. However, their sampling began following spring runoff, and therefore may not have captured the period when stream chemical concentrations and characteristics are changing drastically in snowmelt-dominated systems [Boyer et al., 1997; Lewis and Grant, 1979]. Wurtsbaugh et al. [2005] also argued that lakes would dampen nutrient pulses through watersheds and used a mixed-reactor model to demonstrate the possible magnitude of this effect.

[47] We observed an inverse relationship between lake outflow DOC temporal variability and the size of the lake (Table 4), suggesting that the extent to which lakes can stabilize temporal variability in DOC concentration in mountain landscapes is related to their storage capacity. Furthermore, we observed an inverse relationship with inflow DOC variability and the volume of the closest upstream lake, indicating that upstream water residence time can regulate downstream DOC temporal variability.

[48] Water residence time and flushing rates are related to both watershed and lake size. Lake: watershed area ratios (i.e., drainage ratio) provide insight into the amount of water being routed from the surrounding landscape to a lake of a known size. Thus, the drainage ratio can provide considerable information on lake storage capacity and flushing rates [Canham et al., 2004] and boreal DOC concentration [Engstrom, 1987; Kortelainen, 1993; Rasmussen et al., 1989]. We observed negative relationships between drainage ratios and DOM variability (Table 4). We also observed a negative correlation, albeit not as strong for DOM characteristics $\left(\mathrm{SUVA}_{254}\right)$, between DOM variability and lake volume. These results illustrate that both lake volume and watershed area influence DOM temporal variability.

[49] Upstream watershed characteristics also appear to influence DOM temporal variability. Increasing percentages of upstream lake area dampened temporal variability in DOC concentrations (Table 4). Additionally, we observed strong relationships between the temporal variability of SUVA $_{254}$ and watershed land cover characteristics, where the greater the $\%$ barren area and lower the $\%$ vegetated area, the greater the variability. Similar to our results, Little et al. [2008] found the proportion of barren land to be a significant predictor of $\mathrm{N}$ (primarily $\mathrm{DON}$ ) export during base flow conditions in Chilean watersheds, and attributed this result to a low capacity for water and nutrient retention.

[50] DOM temporal patterns were different between most lake inflows and outflows (Table 5). However, two (HR and LRF) of our seven study watersheds did not exhibit a significant difference in DOC temporal patterns between inflow and outflow streams. These two watersheds have extremely low residence times during base flow ( 0.29 and 0.02 years, respectively) conditions (Table 1 ), and residence times would be even lower during snowmelt conditions [Arp et al., 2006]. Therefore, high flushing rates likely resulted in the decreased buffering capacity of these lakes [Arnott et al., 2003]. Additionally, both of these lakes are influenced strongly by relatively close upstream lakes (Figure 1).

[51] Similar to temporal patterns of DOC concentration, DOM characteristics in lake inflow streams were more temporally dynamic than lake outflow streams (Figure 4 and Table 3). Surprisingly, in late July and early August (approximate days of the year 200-214), SUVA $_{254}$ values 
increased in lake inflows. This shift in DOM characteristics was more dramatic in lake inflows than outflows, and may be a result of dramatic decreases in lake inflow DOC concentrations (Figure 2). However, lakes buffered outflow streams from this increase in aromatic DOM observed in the inflows during mid-late summer (Figure 4), which may be a result of microbial DOM production and processing within the lakes [Goodman, 2010].

[52] Our DOC:DON results illustrate the high temporal variability of DOC:DON ratios (Table 3), which may be a result of high variability of DON analytical measurements and/or differences in flushing rates [Kaiser and Zech, 2000; Kaushal and Lewis, 2003] and cycling [Caraco and Cole, 2003; Kaushal and Lewis, 2005; Wiegner and Seitzinger, 2001]. Additionally, rapid uptake of DON can occur in N-limited systems [Kaushal and Lewis, 2005; Stepanauskas et al., 2000], such as the Sawtooth Mountains, which further obscures the use of DOC:DON ratios as an indicator of source DOM quality and bioavailability. Kaushal and Lewis [2005] found DOC bioavailability to be related to nonhumic (i.e., carbohydrates) fraction $\mathrm{C}: \mathrm{N}$ ratio, yet a substantial portion of DOC is humic substances [Hood et al., 2003; Kaushal and Lewis, 2005]. Similarly, DOC:DON ratios of DOM isolates, such as fulvic and transphilic acids, may be a more reliable indicator of DOM temporal variability in chemical characteristics [Hood et al., 2005]. Therefore, we suggest care should be taken when evaluating DOC:DON ratios as an indicator of DOM bioavailability, and further suggest the use of DOM chemical isolates or a large sample size when attempting to evaluate DOM characteristics using DOC: DON ratio.

\subsection{Controls on DOC Dynamics}

[53] Annual export from our study watersheds was similar to those reported from Colorado Front Range systems $(\sim 11-$ $16 \mathrm{~kg} \mathrm{C} \mathrm{ha}^{-1}$; Table 6) [Hood et al., 2003], albeit in the low range of DOC yields across the United States, $7-74 \mathrm{~kg} \mathrm{C} \mathrm{ha}^{-1}$ [Aitkenhead and McDowell, 2000; Tate and Meyer, 1983]. Similar to other studies, DOC export in our systems was driven by spring snowmelt runoff [Baker et al., 2000; Boyer et al., 1997; Kortelainen et al., 1997; Schindler et al., 1997].

[54] Recent studies have shown that lakes can be a sink for inorganic nutrients [Brown et al., 2008; Kling et al., 2000; Robinson and Matthaei, 2007], and may be a source of particulate and dissolved organic nutrients [Brown et al., 2008; Robinson and Matthaei, 2007]. Furthermore, Brown et al. [2008] and Wurtsbaugh et al. [2005] suggested that lakes may switch from sinks to sources of nitrogen from spring snowmelt to summer base flow. Our results support this hypothesis. We observed a shift in the role of lakes from a DOC sink to a source (that is, in-lake DOC production increased) throughout the summer, as evaluated by differences in DOC concentration between lake inflows and outflows relative to the inflow concentration (Figure 6).

[55] Following peak snowmelt discharge in early June, DOC production in lakes increased for approximately 2 months, which may be a result of increased lake primary production [Crump et al., 2003]. DOC and DON production in lakes has been observed in small oligotrophic [Kling et al., 2000; Lockwood, 2009] and eutrophic [Fairchild and Velinsky, 2006] lakes and ponds. Our prediction that larger lakes would have greater DOC production due to longer residence time was not supported and may be a result of the inherently low pelagic primary production of these systems [Budy et al., 1995].

[56] The fact that the percentage of DOC production declined dramatically in all lakes by mid August, in accordance with shifts in $\mathrm{SUVA}_{254}$ (i.e., aromaticity increased, lower quality carbon; Figure 4) suggests a shift in DOM source and/or microbial processing [Goodman, 2010]. Previous work in these systems indicates that in July and August, nutrients (i.e., $\mathrm{N}$ and $\mathrm{P}$ ) become limiting to autotrophic [Marcarelli and Wurtsbaugh, 2007; Spaulding, 1993] and heterotrophic [Goodman, 2010] production and processing. Thus, altered microbial processes due to nutrient limitation may have altered inflow DOM characteristics. Conversely, in Bull Trout and Stanley Lake we observed higher SUVA 254 values in the lake outflow than inflow (Figure 4 and Table 3 ). This result is likely due to the fact Bull Trout and Stanley Lakes contains dense submerged macrophytes (W. Wurtsbaugh, unpublished data, 2008), which likely contribute large amounts of DOM to the lake and lake outflow [Goodman, 2010; Rich and Wetzel, 1978].

[57] Previous research has shown that lakes in oligotrophic boreal systems can decrease annual DOC export [Mattsson et al., 2005], while autotrophic production in eutrophic lakes can increase annual DOC production [Fairchild and Velinsky, 2006]. We observed a shift in the role of oligotrophic subalpine lakes over time, where lakes decreased DOC export during the spring, and increased DOC export during the summer (Table 6). This higher DOC export during base flow conditions results in an increase in annual DOC export and may provide an important DOC source to downstream locations at a time when the terrestrial DOC supply has been exhausted [Boyer et al., 1997; Brooks et al., 1999; Hood et al., 2003; Hornberger et al., 1994].

[58] Six of the seven lakes we studied exported more DOC than was imported. Two lakes (Bull Trout and Stanley) that have extensive macrophyte beds also had the highest net production of DOC (Figure 6), suggesting that in-lake primary production may be quite important. The lakes also receive particulate organic carbon, particularly during spring runoff. Based on previous work on nitrogen import to Bull Trout Lake [Hall et al., 2009], we calculate that the inflow stream delivered an average of $0.23 \mathrm{mg}$ POC L ${ }^{-1}$ during the descending limb of the hydrograph, and concentrations as high as $2.9 \mathrm{mg} \mathrm{C} \mathrm{L}^{-1}$ occurred during a spate (B. Hall, unpublished data, 2002). Much of this POC can be processed in lakes and likely contributes to the higher DOC concentrations in the outflows than in the inflows [Cole et al., 2002]. Although net export of organic matter may allude to a positive or autotrophic metabolic balance [Lovett et al., 2006], without a complete carbon budget or measurements of $\mathrm{CO}_{2}$ saturation it is not possible to assess whether the lakes are heterotrophic or autotrophic [Duarte and Prairie, 2005].

[59] One limitation for the interpretation of DOM fluxes in our study is that we could not account for all of water flowing into the lakes. Gross and Wurtsbaugh [1994] calculated that, on average, $6 \%$ of the total inflow of Sawtooth Lakes is from nonchannelized hillslope runoff. Hence, we were forced to assume that inflow volumes were equal to outflow volumes. We also assumed that the unaccounted for water had DOM concentrations similar to those measured in the inflow streams. We believe that a substantial portion of 
unaccounted water is from large numbers of rivulets that entered around the lake during snowmelt, but it is reasonable to assume that their DOM concentrations were approximately like those in the mainstreams. Lake evaporation was also not measured, and could have contributed somewhat to the increased concentrations of DOC in the lake outflow, however lake evaporation is small in this mountainous region [Molnau et al., 1992].

[60] Our study characterized the ability of lakes to buffer DOM temporal patterns in mountain streams by evaluating how the function of subalpine lakes can switch throughout a sampling season. Our results illustrate that lakes within highelevation ecosystems can buffer DOM temporal patterns in streams, by acting as a DOM sink during springtime snowmelt flushing and a DOM source during summer base flow. Therefore, lakes dampen snowmelt-flushing responses in lake outflows and increase DOM export during base flow, ultimately buffering solute fluxes by lakes in subalpine regions. The fact that lake inflow variability was strongly related to \% upstream lake area further illustrates the ability of lakes to reduce the control of hydrologic transport on stream DOM dynamics. Our results demonstrate that oligotrophic lakes within mountain fluvial networks can play a role as a landscape regulator of DOC concentration and export, and may provide an important energy source to downstream locations when terrestrial supplies have been exhausted. As such we suggest that mountain lakes provide stability to surface stream networks.

[61] Acknowledgments. This manuscript was greatly improved by the suggestions of two anonymous reviewers. We also thank Nora Burbank and John Olsen for GIS work and Tim Covino, Brian McGlynn, and Caleb Izdepski for the hydrology data. We thank Ian Washbourne and Angie Benedetto for help in the laboratory and with chemical analysis. We thank Angie Benedetto, Chelsea Crenshaw, Natalie Day, Dave Epstein, Michelle Kang, Jason Reed, Caleb Izdepski, Scarlett Vallaire, and Ian Washbourne for help in field. Susan Durham assisted with statistical analyses and suggested using nonparametric ANCOVA. We thank Steve Berukoff and Jeff Taylor for their help with the data and error analysis. This work was funded in part by grants from the Ecology Center at Utah State University and the National Science Foundation (DEB 05-19327 to Wayne Wurtsbaugh and Michelle Baker and DEB 05-19264 to Brian McGlynn).

\section{References}

Aitkenhead, J. A., and W. H. McDowell (2000), Soil C:N ratio as a predictor of annual riverine DOC flux at local and global scales, Global Biogeochem. Cycles, 14(1), 127-138, doi:10.1029/1999GB900083.

Arnott, S. E., P. J. Dillon, K. Somers, and B. Keller (2003), Inter- and intraannual chemical variability during the ice-free season in lakes with different flushing rates and acid deposition histories, Environ. Monit. Assess., 88, 21-37, doi:10.1023/A:1025540217174.

Arp, C. D., M. N. Gooseff, M. A. Baker, and W. Wurtsbaugh (2006), Surface-water hydrodynamics and regimes of a small mountain streamtake ecosystem, J. Hydrol. [Amsterdam], 329(3-4), 500-513, doi:10.1016/j.jhydrol.2006.03.006.

Arp, C. D., J. C. Schmidt, M. A. Baker, and A. K. Myers (2007), Stream geomorphology in a mountain lake district: Hydraulic geometry, sediment sources and sinks, and downstream lake effects, Earth Surf. Processes Landforms, 32(4), 525-543, doi:10.1002/esp.1421.

Baker, M. A., H. M. Valett, and C. N. Dahm (2000), Organic carbon supply and metabolism in a shallow groundwater ecosystem, Ecology, 81(11), 3133-3148, doi:10.1890/0012-9658(2000)081[3133:OCSAMI]2.0. $\mathrm{CO} ; 2$.

Battin, T. J., S. Luyssaert, L. A. Kaplan, A. K. Aufdenkampe, A. Richter, and L. J. Tranvik (2009), The boundless carbon cycle, Nat. Geosci., 2, 598-600, doi:10.1038/ngeo618.

Benner, R. (2003), Molecular indicators of the bioavailability of dissolved organic matter, in Aquatic Ecosystems: Interactivity of Dissolved Organic
Matter, edited by S. E. G. Findlay and R. L. Sinsabaugh, pp. 121-137, Academic, San Diego, Calif.

Borgert, J. A., K. A. Lundeen, and G. D. Thackray (1999), Glacial geology of the southeastern Sawtooth Mountains, in Guidebook to the Geology of Eastern Idaho, edited by S. S. Hughes and G. D. Thackray, pp. 205-217, Idaho Mus. of Nat. Hist., Pocatello, Idaho.

Boyer, E. W., G. M. Hornberger, K. E. Bencala, and D. M. McKnight (1997), Response characteristics of DOC flushing in an alpine catchment, Hydrol. Processes, 11(12), 1635-1647, doi:10.1002/(SICI)10991085(19971015)11:12<1635::AID-HYP494>3.0.CO;2-H.

Breault, R. F., J. A. Colman, G. R. Aiken, and D. McKnight (1996), Copper speciation and binding by organic matter in copper-contaminated streamwater, Environ. Sci. Technol., 30(12), 3477-3486, doi:10.1021/ es9601301.

Brooks, P. D., D. M. McKnight, and K. E. Bencala (1999), The relationship between soil heterotrophic activity, soil dissolved organic carbon (DOC) leachate, and catchment-scale DOC export in headwater catchments, Water Resour. Res., 35, 1895-1902, doi:10.1029/1998WR900125.

Brown, P. D., W. A. Wurtsbaugh, and K. R. Nydick (2008), Lakes and forests as determinants of downstream nutrient concentrations in small mountain watersheds, Arct. Antarct. Alp. Res., 40(3), 462-469, doi:10.1657/15230430(07-052)[BROWN]2.0.CO;2.

Budy, P., C. Luecke, W. A. Wurtsbaugh, and H. P. Gross (1995), Limnology of Sawtooth Valley lakes with respect to potential growth of juvenile Snake River sockeye-salmon, Northwest Sci., 69(2), 133-150.

Canham, C. D., M. L. Pace, M. J. Papaik, A. G. B. Primack, K. M. Roy, R. J. Maranger, R. P. Curran, and D. M. Spada (2004), A spatially explicit watershed-scale analysis of dissolved organic carbon in Adirondack lakes, Ecol. Appl., 14(3), 839-854, doi:10.1890/02-5271.

Caraco, N. F., and J. J. Cole (2003), The importance of organic nitrogen production in aquatic systems: A landscape perspective, in Aquatic Ecosystems: Interactivity of Dissolved Organic Matter, edited by S. E. G. Findlay and R. L. Sinsabaugh, pp. 263-279, Academic, San Diego, Calif. Cattaneo, A., and Y. T. Prairie (1995), Temporal variability in the chemical characteristics along the Rivière De L'Achigan: How many samples are necessary to describe stream chemistry?, Can. J. Fish. Aquat. Sci., 52(4), 828-835, doi:10.1139/f95-082.

Cole, J. J., S. R. Carpenter, J. F. Kitchell, and M. L. Pace (2002), Pathways of organic carbon utilization in small lakes: Results from a whole-lake C-13 addition and coupled model, Limnol. Oceanogr., 47(6), 1664-1675, doi:10.4319/lo.2002.47.6.1664.

Cole, J. J., S. R. Carpenter, M. L. Pace, M. C. Van de Bogert, J. L. Kitchell, and J. R. Hodgson (2006), Differential support of lake food webs by three types of terrestrial organic carbon, Ecol. Lett., 9(5), 558-568, doi:10.1111/j.1461-0248.2006.00898.x.

Crump, B. C., G. W. Kling, M. Bahr, and J. E. Hobbie (2003), Bacterioplankton community shifts in an arctic lake correlate with seasonal changes in organic matter source, Appl. Environ. Microbiol., 69(4), 2253-2268, doi:10.1128/AEM.69.4.2253-2268.2003.

Downing, J. A. (1979), Aggregation, transformation, and the design of benthos sampling programs, J. Fish. Res. Board Can., 36(12), 1454-1463, doi:10.1139/f79-212.

Downing, J. A., et al. (2006), The global abundance and size distribution of lakes, ponds, and impoundments, Limnol. Oceanogr., 51(5), 2388-2397, doi:10.4319/lo.2006.51.5.2388

Duarte, C. M., and Y. T. Prairie (2005), Prevalence of heterotrophy and atmospheric $\mathrm{CO}_{2}$ emissions from aquatic ecosystems, Ecosystems, 8, 862-870, doi:10.1007/s10021-005-0177-4.

Engstrom, D. R. (1987), Influence of vegetation and hydrology on the humus budgets of Labrador lakes, Can. J. Fish. Aquat. Sci., 44(7), 1306-1314, doi:10.1139/f87-154.

Essington, T. E., and S. R. Carpenter (2000), Nutrient cycling in lakes and streams: Insights from a comparative analysis, Ecosystems, 3, 131-143, doi:10.1007/s100210000015.

Fairchild, G. W., and D. J. Velinsky (2006), Effects of small ponds on streamwater chemistry, Lake Reservoir Manage., 22(4), 321-330, doi:10.1080/07438140609354366.

Finlay, J., J. Neff, S. Zimov, A. Davydova, and S. Davydov (2006), Snowmelt dominance of dissolved organic carbon in high-latitude watersheds: Implications for characterization and flux of river DOC, Geophys. Res. Lett., 33, L10401, doi:10.1029/2006GL025754.

Goodman, K. J. (2010), The effect of in-line lakes on dissolved organic matter dynamics in mountain streams, Ph.D. dissertation, 169 pp., Utah State Univ., Logan. [Available at http://digitalcommons.usu.edu/etd/702/.] Gross, H. P., and W. A. Wurtsbaugh (1994), Water and nutrient budgets of the Sawtooth Valley lakes, in Snake River Sockeye Salmon Habitat and Limnological Research: Annual Report 1993, Proj. 91-7 1, edited by D. Teuscher et al., pp. 7-29, Bonneville Power Admin., U. S. Dep. of Energy, Portland, Ore. 
Hall, R. O., M. A. Baker, C. D. Arp, and B. J. Koch (2009), Hydrologic control of nitrogen uptake, storage, and export in a mountain stream, Limnol. Oceanogr., 54(6), 2128-2142, doi:10.4319/lo.2009.54.6.2128.

Hodgkins, G. A., R. W. Dudley, and T. G. Huntington (2003), Changes in the timing of high river flows in New England over the 20th century, J. Hydrol. [Amsterdam], 278(1-4), 244-252, doi:10.1016/S0022-1694(03) 00155-0.

Hood, E., D. M. McKnight, and M. W. Williams (2003), Sources and chemical character of dissolved organic carbon across an alpine/subalpine ecotone, Green Lakes Valley, Colorado Front Range, United States, Water Resour. Res., 39(7), 1188, doi:10.1029/2002WR001738.

Hood, E., M. W. Williams, and D. M. McKnight (2005), Sources of dissolved organic matter (DOM) in a Rocky Mountain stream using chemical fractionation and stable isotopes, Biogeochemistry, 74(2), 231-255, doi:10.1007/s10533-004-4322-5.

Hood, E., M. N. Gooseff, and S. L. Johnson (2006), Changes in the character of stream water dissolved organic carbon during flushing in three small watersheds, Oregon, J. Geophys. Res., 111, G01007, doi:10.1029/ 2005JG000082.

Hornberger, G. M., K. E. Bencala, and D. M. McKnight (1994), Hydrological controls on dissolved organic-carbon during snowmelt in the Snake River near Montezuma, Colorado, Biogeochemistry, 25(3), 147-165, doi:10.1007/BF00024390.

Ito, M., M. J. Mitchell, C. T. Driscoll, R. M. Newton, C. E. Johnson, and K. M. Roy (2007), Controls on surface water chemistry in two lakewatersheds in the Adirondack region nitrogen solute of New York: Differences in sources and sinks, Hydrol. Processes, 21(10), 1249-1264, doi:10.1002/hyp.6297.

Joffre, R., G. I. Agren, D. Gillon, and E. Bosatta (2001), Organic matter quality in ecological studies: Theory meets experiment, Oikos, 93(3), 451-458, doi:10.1034/j.1600-0706.2001.930310.x.

Kaiser, K., and W. Zech (2000), Sorption of dissolved organic nitrogen by acid subsoil horizons and individual mineral phases, Eur. J. Soil Sci., 51(3), 403-411, doi:10.1046/j.1365-2389.2000.00320.x.

Kaplan, L. A. (1994), A field and laboratory procedure to collect, process, and preserve fresh-water samples for dissolved organic-carbon analysis, Limnol. Oceanogr., 39(6), 1470-1476, doi:10.4319/lo.1994.39.6.1470.

Kaste, O., J. L. Stoddard, and A. Henriksen (2003), Implication of lake water residence time on the classification of Norwegian surface water sites into progressive stages of nitrogen saturation, Water Air Soil Pollut., 142, 409-424, doi:10.1023/A:1022015814800.

Kaushal, S. S., and W. M. Lewis (2003), Patterns in the chemical fractionation of organic nitrogen in Rocky Mountain streams, Ecosystems, 6(5), 483-492, doi:10.1007/s10021-003-0175-3.

Kaushal, S. S., and W. M. Lewis (2005), Fate and transport of organic nitrogen in minimally disturbed montane streams of Colorado, USA, Biogeochemistry, 74(3), 303-321, doi:10.1007/s10533-004-4723-5.

Kling, G. W., G. W. Kipphut, M. M. Miller, and W. J. O’Brien (2000), Integration of lakes and streams in a landscape perspective: The importance of material processing on spatial patterns and temporal coherence, Freshwater Biol., 43(3), 477-497, doi:10.1046/j.1365-2427.2000.00515.x.

Kortelainen, P. (1993), Content of total organic carbon in Finnish lakes and its relationship to catchment characteristics, Can. J. Fish. Aquat. Sci., 50(7), 1477-1483, doi:10.1139/f93-168.

Kortelainen, P., S. Saukkonen, and T. Mattsson (1997), Leaching of nitrogen from forested catchments in Finland, Global Biogeochem. Cycles, 11, 627-638, doi:10.1029/97GB01961.

Laurion, I., W. F. Vincent, and D. R. S. Lean (1997), Underwater ultraviolet radiation: Development of spectral models for northern high latitude lakes, Photochem. Photobiol., 65(1), 107-114.

Lepistö, A., K. Granlund, P. Kortelainen, and A. Röike (2006), Nitrogen in river basins: Sources, retention in the surface waters and peatlands, and fluxes to estuaries in Finland, Sci. Total Environ., 365, 238-259, doi:10.1016/j.scitotenv.2006.02.053.

Lewis, W. M., Jr., and M. C. Grant (1979), Relationships between steam discharge and yield of dissolved substances from a Colorado mountain watershed, Soil Sci., 128, 353-363, doi:10.1097/00010694-19791200000007.

Little, C., D. Soto, A. Lara, and J. G. Cuevas (2008), Nitrogen exports at multiple-scales in a southern Chilean watershed (Patagonian Lakes district), Biogeochemistry, 87(3), 297-309, doi:10.1007/s10533-008-9185-8.

Lockwood, R. S. (2009), Nitrogen transport, transformation and cycling through a mountain lake, Bull Trout Lake, Idaho, USA, M.S. thesis, 45 pp., Utah State Univ., Logan.

Lovett, G. M., C. D. Canham, M. A. Arthur, K. C. Weathers, and R. D. Fitzhugh (2006), Forest ecosystem responses to exotic pests and pathogens in eastern North America, BioScience, 56, 395-405, doi:10.1641/ 0006-3568(2006)056[0395:FERTEP]2.0.CO;2.
Marcarelli, A. M., and W. A. Wurtsbaugh (2007), Effects of upstream lakes and nutrient limitation on periphytic biomass and nitrogen fixation in oligotrophic, subalpine streams, Freshwater Biol., 52(11), 2211-2225, doi:10.1111/j.1365-2427.2007.01851.x.

Marschner, B., and K. Kalbitz (2003), Controls of bioavailability and biodegradability of dissolved organic matter in soils, Geoderma, 113(3-4), 211-235, doi:10.1016/S0016-7061(02)00362-2.

Martin, S. L., and P. A. Soranno (2006), Lake landscape position: Relationships to hydrologic connectivity and landscape features, Limnol. Oceanogr. 51(2), 801-814, doi:10.4319/1o.2006.51.2.0801

Mattsson, T., P. Kortelainen, and A. Röike (2005), Export of DOM from boreal catchments: Impacts of land use cover and climate, Biogeochemistry, 76, 373-394, doi:10.1007/s10533-005-6897-x

McGlynn, B. L., and J. J. McDonnell (2003), Role of discrete landscape units in controlling catchment dissolved organic carbon dynamics, Water Resour. Res., 39(4), 1090, doi:10.1029/2002WR001525.

McKnight, D., E. M. Thurman, R. L. Wershaw, and H. Hemond (1985), Biogeochemistry of aquatic humic substances in Thoreau Bog, Concord, Massachusetts, Ecology, 66, 1339-1352.

McKnight, D. M., K. E. Bencala, G. W. Zellweger, G. R. Aiken, G. L. Feder, and K. A. Thorn (1992), Sorption of dissolved organic-carbon by hydrous aluminum and iron-oxides occurring at the confluence of deer creek with the Snake River, Summit County, Colorado, Environ. Sci. Technol., 26(7), 1388-1396, doi:10.1021/es00031a017.

McKnight, D. M., R. Harnish, R. L. Wershaw, J. S. Baron, and S. Schiff (1997), Chemical characteristics of particulate, colloidal, and dissolved organic material in Loch Vale Watershed, Rocky Mountain National Park, Biogeochemistry, 36(1), 99-124, doi:10.1023/A:1005783812730.

Menzel, D. W., and R. F. Vacarro (1964), The measurement of dissolved and particulate organic carbon in seawater, Limnol. Oceanogr., 9(1), 138-142, doi:10.4319/lo.1964.9.1.0138.

Molnau, M., K. C. S. Kpordze, and K. L. Craine (1992), Monthly shallow pond evaporation in Idaho, Pap. PNW92-111, Am. Soc. of Agric. Eng., St. Joseph, Mich.

Mulholland, P. J., and W. R. Hill (1997), Seasonal patterns in streamwater nutrient and dissolved organic carbon concentrations: Separating catchment flow path and in-stream effects, Water Resour. Res., 33, 1297-1306, doi:10.1029/97WR00490.

National Atmospheric Deposition Program (2001), National Atmospheric Deposition Program: 2000 annual summary, NADP Data Rep. 2001-01, Ill. State Water Surv., Champaign.

Pace, M. L., and J. J. Cole (2002), Synchronous variation of dissolved organic carbon and color in lakes, Limnol. Oceanogr., 47(2), 333-342, doi:10.4319/1o.2002.47.2.0333.

Rantakari, M., P. Kortelainen, J. Vuorenmaa, J. Mannio, and M. Forsius (2004), Finnish lake survey: The role of catchment attributes in determining nitrogen, phopsphorus, and organic carbon concentrations, Water Air Soil Pollut. Focus, 4, 683-699, doi:10.1023/B:WAFO.0000028387.61261.96.

Rasmussen, J. B., L. Godbout, and M. Schallenberg (1989), The humic content of lake water and its relationship to watershed and lake morphometry, Limnol. Oceanogr., 34(7), 1336-1343, doi:10.4319/lo.1989.34.7.1336.

Rich, P. H., and R. G. Wetzel (1978), Detritus in the lake ecosystem, Am. Nat., 112, 57-71, doi:10.1086/283252.

Riera, J. L., J. J. Magnuson, T. K. Kratz, and K. E. Webster (2000), A geomorphic template for the analysis of lake districts applied to the Northern Highland Lake District, Wisconsin, USA, Freshwater Biol., 43(3), 301-318, doi:10.1046/j.1365-2427.2000.00567.x.

Robinson, C. T., and S. Matthaei (2007), Hydrological heterogeneity of an alpine stream-lake network in Switzerland, Hydrol. Processes, 21(23), 3146-3154, doi:10.1002/hyp.6536.

Sauer, V. B., and R. W. Meyer (1992), Determination of error in individual discharge measurements, U.S. Geol. Surv. Open File Rep., 92-144, 26 pp., U.S. Dep. of the Inter., Norcross, Ga.

Schiff, S. L., R. Aravena, S. E. Trumbore, and P. J. Dillon (1990), Dissolved organic carbon cycling in forested watersheds: A carbon isotope approach, Water Resour. Res., 26, 2949-2957, doi:10.1029/WR026i012p02949.

Schindler, D. W., P. J. Curtis, S. E. Bayley, B. R. Parker, K. G. Beaty, and M. P. Stainton (1997), Climate-induced changes in the dissolved organic carbon budgets of boreal lakes, Biogeochemistry, 36, 9-28, doi:10.1023 A: 1005792014547

Schlesinger, W. H., and J. M. Melack (1981), Transport of organic carbon in the world rivers, Tellus, 33, 172-187, doi:10.1111/j.2153-3490.1981. tb01742.x

Scully, N. M., and D. R. S. Lean (1994), The attenuation of UV radiation in temperate lakes, Arch. Hydrobiol., 43, 135-144.

Sebestyen, S. D., E. W. Boyer, J. B. Shanley, C. Kendall, D. H. Doctor, G. R. Aiken, and N. Ohte (2008), Sources, transformations, and hydrological processes that control stream nitrate and dissolved organic matter concen- 
trations during snowmelt in an upland forest, Water Resour. Res., 44 , W12410, doi:10.1029/2008WR006983.

Solórzano, L. (1969), Determination of ammonia in natural water by the phenolhypochlorite method, Limnol. Oceanogr., 14(5), 799-801, doi:10.4319/lo.1969.14.5.0799.

Soranno, P. A., et al. (1999), Spatial variation among lakes within landscapes: Ecological organization along lake chains, Ecosystems, 2(5), 395-410, doi:10.1007/s100219900089.

Spaulding, S. (1993), Snake River sockeye salmon (oncorhynchus nerka) habitat/limnologic research: Annual report 1992, Bonneville Power Admin., U.S. Dep. of Energy, Portland, Ore.

Stepanauskas, R., H. Laudon, and N. O. G. Jorgensen (2000), High DON bioavailability in boreal streams during a spring flood, Limnol. Oceanogr. 45(6), 1298-1307, doi:10.4319/1o.2000.45.6.1298.

Tate, C. M., and J. L. Meyer (1983), The influence of hydrologic conditions and successional state on dissolved organic-carbon export from forested watersheds, Ecology, 64(1), 25-32, doi:10.2307/1937325.

Taylor, J. R. (1997), An Introduction to Error Analysis: The Study of Uncertainties in Physical Measurements, 2nd ed., Univ. Sci. Books, Sausalito, Calif.

Valderrama, J. C. (1981), The simultaneous analysis of total nitrogen and total phosphorus in natural waters, Mar. Chem., 10, 109-122, doi:10.1016/0304-4203(81)90027-X.

Weishaar, J. L., G. R. Aiken, B. A. Bergamaschi, M. S. Fram, R. Fujii, and K. Mopper (2003), Evaluation of specific ultraviolet absorbance as an indicator of the chemical composition and reactivity of dissolved organic carbon, Environ. Sci. Technol., 37(20), 4702-4708, doi:10.1021 es030360x.
Westerhoff, P., G. Aiken, G. Amy, and J. Debroux (1999), Relationships between the structure of natural organic matter and its reactivity towards molecular ozone and hydroxyl radicals, Water Res., 33(10), 2265-2276, doi:10.1016/S0043-1354(98)00447-3

Wiegner, T. N., and S. P. Seitzinger (2001), Photochemical and microbial degradation of external dissolved organic matter inputs to rivers, Aquat. Microb. Ecol., 24, 27-40, doi:10.3354/ame024027.

Williamson, C. E., and K. C. Rose (2009), Ultraviolet insights: Attempting to resolve enigmatic patterns in pelagic freshwaters-The historical context and a view to the future, Int. Rev. Hydrobiol., 94(2), 129-142, doi:10.1002/iroh.200811099.

Wurtsbaugh, W., H. Gross, C. Luecke, and P. Budy (1997), Nutrient limitation of oligotrophic sockeye salmon lakes of Idaho (USA), Verh. Int Ver. Theor. Angew. Limnol., 26, 413-419.

Wurtsbaugh, W. A., M. A. Baker, H. P. Gross, and P. D. Brown (2005), Lakes as nutrient "sources" for watersheds: A landscape analysis of the temporal flux of nitrogen through sub-alpine lakes and streams, Verh. Int. Ver. Theor. Angew. Limnol., 29, 645-649.

Young, S. G., and A. W. Bowman (1995), Nonparametric analysis of covariance, Biometrics, 51, 920-931, doi:10.2307/2532993.

M. A. Baker, Department of Biology, 5305 Old Main Hill, Utah State University, Logan, UT 84322, USA.

K. J. Goodman, National Ecological Observatory Network, 1685 38th St. Ste. 100, Boulder, CO 80301, USA. (keliusu@gmail.com)

W. A. Wurtsbaugh, Watershed Sciences Department, 5210 Old Main Hill, Utah State University, Logan, UT 84322-5210, USA. 